NBER WORKING PAPER SERIES

\title{
COMPULSORY VOTING, TURNOUT, AND GOVERNMENT SPENDING: EVIDENCE FROM AUSTRIA
}

\author{
Mitchell Hoffman \\ Gianmarco León \\ María Lombardi \\ Working Paper 22221 \\ http://www.nber.org/papers/w22221 \\ NATIONAL BUREAU OF ECONOMIC RESEARCH \\ 1050 Massachusetts Avenue \\ Cambridge, MA 02138 \\ May 2016
}

We thank Kevin Bryan, Jeremy Ferwerda, Rui de Figueiredo, Fred Finan, Ted Miguel, John Morgan, Gerard Roland, Francesco Trebbi, and seminar participants for helpful comments. Melina Mattos, Nicholas Roth, and Dijana Zejcirovic provided outstanding research assistance. Hoffman acknowledges support from the Kauffman Foundation, the National Science Foundation IGERT Fellowship, and the Social Science and Humanities Research Council of Canada. Leon acknowledges support from the Spanish Ministry of Economy and Competitiveness, through the Severo Ochoa Programme for Centres of Excellence in R\&D (SEV-2011-0075) and grant ECO2014-55555-P. The views expressed herein are those of the authors and do not necessarily reflect the views of the National Bureau of Economic Research.

NBER working papers are circulated for discussion and comment purposes. They have not been peer-reviewed or been subject to the review by the NBER Board of Directors that accompanies official NBER publications.

(C) 2016 by Mitchell Hoffman, Gianmarco León, and María Lombardi. All rights reserved. Short sections of text, not to exceed two paragraphs, may be quoted without explicit permission provided that full credit, including $(\odot$ notice, is given to the source. 
Compulsory Voting, Turnout, and Government Spending: Evidence from Austria

Mitchell Hoffman, Gianmarco León, and María Lombardi

NBER Working Paper No. 22221

May 2016

JEL No. D72,H10,P16

\section{ABSTRACT}

We study a unique quasi-experiment in Austria, where compulsory voting laws are changed across Austria's nine states at different times. Analyzing state and national elections from 1949-2010, we show that compulsory voting laws with weakly enforced fines increase turnout by roughly 10 percentage points. However, we find no evidence that this change in turnout affected government spending patterns (in levels or composition) or electoral outcomes. Individual-level data on turnout and political preferences suggest these results occur because individuals swayed to vote due to compulsory voting are more likely to be non-partisan, have low interest in politics, and be uninformed.

Mitchell Hoffman

Rotman School of Management

University of Toronto

105 St. George Street

Toronto, ON M5S 3E6

CANADA

and NBER

mitchell.hoffman@ rotman.utoronto.ca

Gianmarco León

Universitat Pompeu Fabra and

Barcelona Graduate School of Economics

Jaume I building, 20.1E74

Ramon Trias Fargas, 25-27

08005 Barcelona, Spain

gianmarco.leon@upf.edu
María Lombardi

Universitat Pompeu Fabra

Jaume I building, 20.1E74

Ramon Trias Fargas, 25-27

08005 Barcelona, Spain

maria.lombardi@upf.edu 


\section{Introduction}

Despite the centrality of elections to democracy, in elections around the world many people fail to vote. Many European countries have seen a steep decline in turnout rates in the past 30 years, with record low rates in the past two (2009 and 2014) elections for the European Parliament. ${ }^{1}$ Ethnic minorities, immigrants, and poor voters in Europe are significantly less likely to vote, potentially distorting the political process (e.g., Gallego, 2007). In the US, turnout also exhibits large disparities along socioeconomic and racial lines. ${ }^{2}$ Such disparities in turnout are believed to cause disadvantaged groups to be under-served by government (e.g., Meltzer and Richard, 1981; Lijphart, 1997).

One policy to help address these issues is to make voting mandatory. As of 2008, 32 countries had a compulsory voting (CV) law in place (Chong and Olivera, 2008), and a higher number had CV at some point during the last 50 years. In March 2015, US President Barack Obama proposed the possibility of CV, arguing "If everyone voted, then it would completely change the political map of this country. The people who tend not to vote are young, they're lower income, they're skewed more heavily towards immigrant groups and minority groups...There's a reason why some folks try to keep them away from the polls." 3 However, little is known empirically about how CV affects voter behavior, politician behavior, or government policy.

We provide empirical evidence on the impact of CV laws on turnout, political competition, and fiscal policy using a unique natural experiment in Austria. Since World War II, Austria's nine states have changed their CV laws at different times for different types of elections. Austria provides a compelling case study for multiple reasons. First, the variation in CV laws is significant across states and over time, providing rich variation for quasi-experimental analysis. Second, like the US and many other countries, Austria exhibits socioeconomic dis-

\footnotetext{
${ }^{1}$ From http://www.europarl.europa.eu/elections2014-results/en/turnout.html, last accessed March 16, 2016.

${ }^{2}$ For example, those with a graduate degree often vote at twice the rate of high school dropouts (Linz et al., 2007). For evidence on racial disparities in turnout, see, e.g., Timpone (1998).

${ }^{3}$ See, e.g., http://www.cnn.com/2015/03/19/politics/obama-mandatory-voting/, accessed March 16, 2016.
} 
parities in turnout, with poor and underserved groups being much less likely to vote than the rich. In addition, as noted by Ferwerda (2014), with the exception of one Swiss canton (Vaud), Austria is the sole modern democracy to have within-country variation in CV for national elections.

In our main results, using state-level voting records on state and national elections from 1949-2010, we find that CV increases turnout from roughly $80 \%$ to $90 \%$. Impacts on turnout vary somewhat across the three types of elections (parliamentary, state, and presidential), but are sizable. Interestingly, however, CV does not appear to affect state-level spending. These "zero effects" are reasonably precisely estimated and robust to different specifications that deal with concerns regarding possible endogenous changes in CV laws.

How could it be that CV had large impacts on turnout, but did not affect policy outcomes? Our analysis shows that despite the large increase in turnout, CV did not affect electoral outcomes: vote shares for liberal parties did not change significantly, nor did the number of parties running for office or the victory margin in state or parliamentary elections.

To complement our main aggregate analysis and dig further into mechanisms, we use repeated cross sections of individual level data to analyze interaction effects of CV laws with voter characteristics. While our statistical power is more limited compared to our main analyses, we find suggestive results that voters swayed to vote because of CV were often female and low-income. They also seem more likely to have low interest in politics, no party affiliation, and be uninformed (as proxied by newspaper reading). While suggestive, these results are consistent with a story where voters who vote or abstain due to the introduction or repeal of CV do not have strong policy or partisan preferences, thereby having little or no effect on electoral outcomes.

Our paper relates to three main literatures. First, an important literature analyzes how changes in turnout and electorate composition affect public policy (Persson and Tabellini, 2000), often looking at the impacts of enfranchising particular groups of people. For example, the enfranchisement of women in the US led to increases in government health expenditures 
(Miller, 2008), as did the adoption of electronic voting in Brazil, which effectively enfranchised illiterate voters (Fujiwara, 2015). Similarly, Naidu (2012) shows that post-Civil War laws restricting voting for blacks in the US South had sizable impacts on public policy. ${ }^{4}$ Our findings do not contradict this literature, but complement it, suggesting that the extent to which changes in turnout affect policy depends importantly on whether these policies affect a group of the population with specific policy preferences.

Second, our paper speaks to the literature on the determinants of voter turnout. Scholars have analyzed interventions aimed at increasing turnout, often using randomized experiments. ${ }^{5}$ In non-experimental studies, a significant literature examines the impact of voting costs, often reaching different results from different changes in costs. ${ }^{6}$ For example, Farber (2009) shows that election holidays and "time-off" have little impact on turnout in the US, whereas Brady and McNulty (2011) show that an increase in voting costs (due to unexpected changes in polling places) reduces turnout. We complement this literature by simultaneously analyzing turnout and government policy.

Two noteworthy recent studies follow this tradition, analyzing how changes in voting costs affect turnout and policy outcomes. Hodler et al. (2015) propose a model of government where higher-skill individuals are more likely to vote. A reduction in voting costs leads to some lower-skill individuals choosing to vote. On one hand, these lower-skill individuals like government spending because a greater share of it is paid for by the rich (Meltzer and Richard, 1981). On the other hand, they invest less in political information than high-skill

\footnotetext{
${ }^{4}$ Other papers in this literature show mixed results of the extension of the voting franchise on redistributive policies (e.g., Husted and Kenny, 1997; Rodriguez, 1999; Gradstein and Milanovic, 2004; Timpone, 2005; Cascio and Washington, 2014). A common message from this literature is that efforts to extend the voting franchise can significantly affect public policy, making it more aligned with voters' preferences. Most of this literature analyzes episodes in which groups with specific policy preferences are de jure or de facto enfranchised, leading elected officials to cater policies toward them.

${ }^{5}$ See Gerber and Green (2012) and the references therein for examples from the large and recent experimental literature on voting.

${ }^{6}$ Weather shocks have been used as exogenous shifts in the cost of voting (e.g., Knack, 1994; Gomez et al., 2007; Hansford and Gomez, 2010; Fraga and Hersh, 2010; Gomez et al., 2007), as have general rules of governance (Hinnerich and Pettersson-Lidbom, 2014; Herrera et al., 2014), candidates' ethnicity (Washington, 2006), and availability of certain information technology (Stromberg, 2004; Enikolopov et al., 2010; Gentzkow, 2006; Gentzkow et al., 2011; Gavazza et al., 2014). Some of these voting cost shifters are unexpected shocks, whereas others could be anticipated by politicians.
} 
voters, making them more likely to be impressionable and thereby driven to choose candidates based on lobby-funded campaign spending instead of government spending. To test the model, they study the staggered introduction of postal voting across Swiss cantons. Postal voting led to increased turnout, lower education of participants, lower political information, and lower welfare spending. Godefroy and Henry (2015) analyze the impact of voting cost shocks on the selection of politicians and discretionary expenditures. Using digestive infections as a shock to voting costs, they find that unanticipated increases in voting costs lead to lower turnout, higher candidate quality, and higher infrastructure expenditures in French cities. We discuss differences between our results and these two studies in Section 4.2.

Third, it relates to a small but burgeoning literature analyzing CV. Among a number of theoretical contributions, Börgers (2004) and Krishna and Morgan (2011) argue that CV reduces welfare, whereas Krasa and Polborn (2009) show that compulsory voting (or costly voting) allows an aggregation of preferences that can increase welfare. In empirical work, Funk (2007) finds that abolishing CV significantly decreased turnout in Switzerland despite the fact that fines were small and not enforced. Her results highlight the expressive value of CV, an interpretation that could also apply to our setting, given the low levels of enforcement of the fines. However, this study does not investigate further the effects of changes in turnout on public policy. In a cross-country study, Chong and Olivera (2008) show that countries with CV have lower income inequality. Fowler (2013) exploits the staggered introduction of CV across Australian states, finding that CV led to large increases in turnout. De Leon and Rizzi (2014) analyze students in Brazil, where voting is voluntary between ages 16 to 18, but mandatory afterward. They find that CV increases turnout, but doesn't affect political information. Using a field experiment in Peru providing information about changes in abstention fines, León (2015) shows that a reduction in the fines decreases turnout, and consistent with our findings, that the reduction is driven by uninformed, uninterested, and centrist voters. However, León (2015) can only analyze policy preferences and can't analyze actual policies as our paper does. A few political science papers involve the specific case of CV in Austria. The first paper 
to explore it was Hirczy (1994), who compared overall voting rates between Austrian states over time; the graphical evidence presented suggests that adoption of CV led to significant increases in turnout. The paper closest (and contemporaneous) to ours is Ferwerda (2014), who analyzes the effects of the repeal of CV by the Austrian parliament in 1992 on turnout and on changes in party vote shares. Although his analysis period is much shorter, the magnitude of the effects found on electoral participation and party vote shares are broadly consistent with ours. ${ }^{7,8}$ Our paper goes beyond these studies in three main ways. First and foremost, not only do we analyze the political consequences of CV, but also impacts on spending, thereby providing the first micro study (for Austria or any other country) to examine how CV affects government spending. Second, we complement the analysis of aggregate data with individual level information on political preferences and voting behavior, allowing us to study the shift in the composition of the pool of voters resulting from CV. Finally, we analyze all elections from 1949-2010 instead of just a subset; this enables us to implement a fixed effects analysis allowing for different state linear trends, ruling out the concern that the effects are only valid in the short term and that we should expect a reversion to the mean.

Section 2 provides background on democratic institutions and CV in Austria. Section 3 describes the data. Section 4 discusses our estimation strategy and shows the results. Section 5 analyzes mechanisms for our results. Section 6 concludes and discusses external validity.

\section{Institutional Background}

\subsection{Democratic Institutions and Budgeting Processes in Austria}

Austria is a federal and parliamentary democracy, composed of nine autonomous states. The National Parliament is composed of two chambers, the National Council (Nationalrat) and the Federal Council (Bundesrat), with legislative authority vested mostly in the former. National

\footnotetext{
${ }^{7}$ Ferwerda (2014) also uses municipal-level data instead of state-level data.

${ }^{8}$ Another contemporaneous paper, Shineman (2014), also uses Austria as a case study to demonstrate the effects of $\mathrm{CV}$ on individual-level political sophistication, finding that both recent and long-term exposure to $\mathrm{CV}$ increase voters' information.
} 
Council members are directly elected for five-year periods by proportional representation, whereas members of the Federal Council are elected by the state legislatures. Austria's executive branch is composed of the Federal President (Bundespräsident), the Federal Chancellor (Bundeskanzler) and the Federal Cabinet. The Federal President is elected by simple majority in a popular election, and the candidates are nominated by party coalitions. The president holds the mostly ceremonial position of head of state. The Federal Cabinet is composed of the Federal Chancellor, the head of government, and a group of ministers, all of whom are appointed by the president. Austrian states are ruled by their own regional parliament (Landtag), a state government (Landesregierung), and a governor (Landeshauptmann). State parliament representatives are directly elected and serve for five-year terms. ${ }^{9}$ Unlike the federal government, state governors are elected by the state parliament.

About $95 \%$ of taxes are collected at the federal level, and are distributed across the three levels of government (federal, state, and local) according to Fiscal Equalization Laws, which last for short periods of time (3-4 years) and are established by a consensus between the federal and regional governments (Blöndal and Bergvall, 2007). Within the two lower levels of government, tax revenues are distributed across the different units according to a formula, which takes into account demographic and revenue criteria. Federal transfers to state governments are classified into two broad categories: (i) funds earmarked for a precise purpose ${ }^{10}$ and (ii) discretionary funds. ${ }^{11}$ Throughout our period of analysis, discretionary funds consistently accounted for about half of the total transfers, giving state governments considerable fiscal autonomy. ${ }^{12}$ States' spending autonomy comes across in the substantial variation in how they choose to allocate their resources. ${ }^{13}$ Although the largest portion of tax revenues

\footnotetext{
${ }^{9}$ An exception to this is the state of Upper Austria, whose representatives serve for six years.

${ }^{10}$ Most of these funds are meant to be spent on wages. For example in 1997, $26 \%$ of states' overall budget was spent on teacher's salaries, which is more than half of the earmarked funds coming from the central government. The remainder of these funds was used for infrastructure expenses, housing subsidies, residential dwelling projects, local transport, disaster control, environmental/agricultural expenses, and health.

${ }^{11} 1948$ Constitutional Law, Sections II and III.

${ }^{12}$ For further details see Gerhard Lehner's 1997 report for the Austrian Institute of Economic Research (WIFO).

${ }^{13}$ During 1980-2012, for example, the government of Burgenland devoted $66 \%$ of its budget to welfare expenditures and only $13 \%$ to infrastructure spending, whereas the neighboring state of Lower Austria spent $43 \%$ of its resources on welfare, and $40 \%$ on infrastructure.
} 
are allocated to the central government, state governments receive a significant portion of the total budget, and are responsible for providing a wide array of public goods and services. In 2006, for example, spending by state governments accounted for $17 \%$ of total spending, with $70 \%$ and $13 \%$ of spending carried out by the central and municipal governments, respectively. Further, state governments are responsible for administering primary education, regional infrastructure, transportation, social welfare, and pensions for state civil servants. ${ }^{14}$

In the postwar period, Austria had four major parties. At the right of the political spectrum are the center-right People's Party (ÖVP) and the right-wing populist Freedom Party of Austria (FPÖ). At the left of the spectrum lie the Social Democratic Party (SPÖ) and the Communist Party of Austria (KPÖ). Other minor parties such as the Green Party, the Allegiance for the Future of Austria, and the Liberal Forum have become a recent part of the political scene.

\subsection{Compulsory Voting in Austria}

Figure 1 summarizes the process by which CV was introduced and later repealed in Austria. The mandate to vote was changed a number times during 1949-2010; whether voting was compulsory varied substantially both across and within states, and depending on the type of election, as seen in Figure 2. CV was first introduced in Austria in the 1929 Constitution. In particular, voting became mandatory for all citizens in presidential elections, but it was up to each state to determine whether voting was mandatory or voluntary in parliamentary and state elections (see Appendix B.1 for further details).

The first presidential election with CV was held in 1951. Up until 1980, there were seven presidential elections, and all of them had CV. However, a 1982 amendment to the Austrian Constitution made voting in presidential elections compulsory only in the states that decided so. In the 1986 presidential elections, the states of Vorarlberg, Tyrol, Styria, and Carinthia

\footnotetext{
${ }^{14}$ In some of these areas the responsibilities of the central and state governments overlap and are thus cofinanced or managed jointly. For further details see the International Monetary Fund Country Report No. $08 / 189$.
} 
decided to keep CV. Furthermore, Carinthia enacted a law establishing CV for parliamentary and state elections. The remaining five states abolished CV in presidential elections after the 1982 amendment.

In 1992, a Federal Constitution amendment by the national parliament withdrew the power of establishing mandatory voting in the national parliament elections from the states (Federal Law Gazette No. 470/1992). Starting in the 1994 parliamentary elections, voting was optional in all states. After this constitutional amendment, the states which still had CV in presidential and state parliament elections started repealing their state laws one by one. ${ }^{15}$ In 1993, Carinthia and Styria eliminated CV for both types of elections. Tyrol repealed CV for state parliament elections in 2002, and Vorarlberg got rid of it before the 2004 elections. After these elections, Tyrol finally repealed CV for presidential elections. Thus, the 2010 presidential elections (the last in our sample) were the first in which voting was voluntary throughout the country.

During the period in which voting was compulsory, local authorities were responsible for issuing fines against the non-voters failing to provide a reasonable excuse for abstaining. ${ }^{16}$ Abstention penalties were extremely rare, since the law allowed for a wide range of excuses for not voting, such as illnesses, professional commitments, urgent family matters, being outside the state during the election, or "other compelling circumstances" due to which the voter could not go to the polls. ${ }^{17}$ Importantly, voters who excused themselves were not required to provide documentation justifying their absence. ${ }^{18}$ Shineman (2014), after doing qualitative

\footnotetext{
${ }^{15}$ Anecdotal information from the state legislature discussions on the elimination of CV shows that this repeal was triggered by the de facto null enforcement of the fines, and by the fact that parliamentary CV had already been repealed in 1992. Specific references can be found in Styria's state parliament session of January 26, 1993, and Tyrol's state parliamentary session of June 30, 2004.

${ }^{16}$ Federal Presidential Election Law, Article 23 and Federal Parliament Election Law, Article 105 (4). We provide details on the maximum fine amounts specified in the law and their evolution in different states in Appendix B.2. While there is information on maximum fine amounts in states, we have limited information on actual fine amounts (for the cases where fines were actually enforced), due to the involvement of local authorities in setting actual fines.

${ }^{17}$ The infrequence of effective punishment is reflected in the state parliament sessions discussing the possible elimination of CV in Tyrol; one deputy argued that he wasn't even aware of any case in which administrative penalties were applied. For further details see the arguments by Deputy Bachmann in Tyrol state parliament session, June 30, 2004.

${ }^{18}$ Only when an administrative penal procedure was initiated against them, abstainers needed to provide
} 
work with Austrian citizens and elites, concludes that fines rarely had real consequences and almost never were enforced. See Appendix B.2 for additional details supporting that fines were weakly enforced.

\section{Data Sources and Descriptive Statistics}

In the empirical analysis, we draw upon three main sources of information. To analyze the effect of $\mathrm{CV}$ laws on voter turnout, political competition and public spending, our initial sample consists of all parliamentary, presidential, and state elections held since the end of World War II until 2010. ${ }^{19}$ For these elections, we hand-collected data on voter turnout, invalid ballots and party vote shares from the Austrian Federal Ministry of the Interior's yearbooks. Second, we draw upon detailed annual information on expenditures by each of the state governments, which is publicly available on the Austrian Statistical Agency's website. Unfortunately, this information is only available since $1980 .{ }^{20}$ In all of our specifications, we also include state-specific, time-varying covariates (i.e., total population and unemployment rates) obtained from the Austrian Statistical Agency.

Table 1 gives descriptive statistics. Average turnout in our sample is relatively high, ranging from $86 \%$ in state elections to $90 \%$ in parliamentary elections. ${ }^{21}$ The average incidence of invalid ballots in these elections is $2 \%$ on average. Both in state and parliamentary elections, voting for the main right wing parties is more prevalent $(52 \%-53 \%)$, while voting for the two

evidence of the reasons for not voting. Appendix B.2 provides further details on the severity and enforcement of abstention sanctions in each state.

${ }^{19}$ We exclude the 1945 elections, just after World War II ended. This election was unusual in many respects, coming quite soon after the war and banning former Nazis (approximately $11 \%$ of the voting age population), who were not allowed to vote until the 1949 election (Bischof and Plasser, 2008). In the period under consideration there were 19 parliamentary elections, 12 presidential elections, and around 11-15 state elections in each of the nine Austrian states.

${ }^{20}$ This restricts our analysis to 10 parliamentary elections, 6 presidential elections and 6-7 state elections in each state. In the Web Appendix, we repeat our main results on turnout, invalid votes and political competition for the restricted period of 1979-2010, and they are qualitatively similar to those in the main text covering 1949-2010.

${ }^{21}$ Turnout is defined in our paper as the proportion of registered voters who showed up to the polls. Registration is automatic for all citizens with a permanent residence in the country. If we only count the most recent elections (e.g., those after 1979), turnout in state (parliamentary) elections averages 80\% (85\%). 
leading leftist parties is around $40 \% .^{22}$

The Austrian Statistical Agency expenditure data include 10 expenditure groupings by year. To simplify exposition and improve statistical precision, we combined the groupings into three broad categories: Administrative, Welfare, and Infrastructure. We define "administrative expenditures" as spending on elected representatives and general administration. "Welfare Expenditures" comprise expenditures on education; health; arts and culture; and social welfare and housing. "Infrastructure Expenditures" are those for construction, transport, and security. ${ }^{23}$ The yearly expenditure data is expressed in millions of 2010 euros. In the 1980-2012 period, a majority of expenses (54\%) were devoted to the social sector, while $25 \%$ of all resources were spent on administration, and the remaining $21 \%$ were devoted to infrastructure. Finally, to understand how CV affects the composition of the electorate, we use the Austrian Social Survey (ASS), a nationally representative survey conducted in 1986, 1993, and 2003. ${ }^{24}$ The survey asks respondents standard questions on demographics, socioeconomic status, education, and importantly, it inquires about voting behavior, and political and social preferences. Table 2 shows the descriptive statistics from our individual level data. ${ }^{25}$

\subsection{Comparing Austria to Other Countries}

Before providing our results, we seek to provide context by comparing Austria to other countries in terms of political behavior. Figure 3 compares turnout rates in Austria and other OECD countries. While Austria has high turnout, it is not an extreme outlier and there are a number of other countries with broadly similar turnout levels. While the median turnout

\footnotetext{
${ }^{22}$ We consider the sum of votes for ÖVP and FPÖ as right wing votes, and the sum of votes for the SPÖ and KPÖ as votes for the left.

${ }^{23}$ Turn to Table A.1 for a detailed description of expenditure areas falling into each of the 10 groupings. Our conclusions are substantively unchanged if we analyze the 10 groupings individually or if we combine the groupings into 3 categories in other ways.

${ }^{24}$ The survey round carried out in 1993 did not include questions on turnout, so we exclude it from our main analysis. For a general description of the waves of the Austrian Social Survey used, see Haller et al. (1987) and Haller et al. (2005).

${ }^{25}$ Our sample includes all respondents reporting whether they voted or not in the previous parliamentary elections. Only $3 \%$ failed to provide this information, and missingness is not correlated with whether there is $\mathrm{CV}$ in their state. $88 \%$ of respondents report having voted in the previous parliamentary elections.
} 
in this sample is $75.7 \%$, turnout in Austrian parliamentary (state) elections when voting was voluntary is $83.8 \%(77.5 \%)$, which places these elections in the $76^{\text {th }}\left(56^{\text {th }}\right)$ percentile of the turnout distribution. ${ }^{26}$

Austrians are quite interested in politics and their political attitudes are quite similar to those observed in citizens of other countries with comparable income levels. Austrians are quite interested in politics. In the 2003 wave of the ASS, 26\% of Austrians reported being "Very Interested in Politics," which is comparable with Switzerland (26.6\%) or Germany (21\%), but slightly higher than other northern European or other rich countries participating in the World Value Survey. ${ }^{27}$ Nonetheless, when we look at other measures of interest in politics and information acquisition (as proxied by reading the newspaper regularly), Austria seems to be quite similar to other OECD countries. While $68.8 \%$ of Austrians in the ASS read the newspaper regularly, $74.8 \%$ of people from other OECD countries in the World Value Survey report having read the newspaper the week before they were surveyed. The level of information acquisition in Austria is below countries like Switzerland (91.3\%), Sweden (94.5\%), or Japan (88.8\%), and only above much less developed democracies like Hungary (56.8\%), Poland (55.1\%), or Spain (62.7\%). Likewise, $11.9 \%$ of Austrians are members of a political party, comparable to $13.4 \%$ of respondents in other OECD countries. These statistics provide reassurance that our results seem unlikely to be due to an unusual institutional context or by political behaviors that are highly specific to Austria.

\footnotetext{
${ }^{26}$ The percentile numbers are calculated relative to elections with voluntary voting between 1979 and 2010 for the OECD countries in Figure 3. Being in the 76th percentile means that average turnout in Austrian parliamentary elections is higher than turnout in $76 \%$ of OECD elections. The state election percentile should be taken with some care because it reflects a comparison of state elections in Austria to national elections in other countries. Beyond OECD countries, there are many low- and middle-income countries with high turnout (e.g., Argentina, Indonesia, and Uruguay, to name a few); see http://www.idea.int/parties/index.cfm.

${ }^{27}$ These statistics are reported in detail in Table A.2. Note that Austria did not participate in the WVS, so the numbers are not strictly comparable, but they do give us a broad sense of how Austrians' political opinions compare to other countries.
} 


\section{Empirical Strategy and Results}

We estimate the effect of CV laws on turnout, invalid ballots, political competition and public spending in different elections. Using a difference-in-difference model, we compare states with and without $\mathrm{CV}$ at different points in time. Our baseline specification is:

$$
y_{s t}=\alpha_{0}+\beta_{1} C V_{s t}+X_{s t} \beta_{2}+\delta_{s}+\nu_{t}+\gamma_{s t}+\epsilon_{s t}
$$

where $y_{s t}$ is an outcome variable in state $s$ and year/election $t ; C V_{s t}$ is a dummy for whether voting was compulsory in year/election $t$ and state $s ; X_{s t}$ is a vector of state-year covariates (population and the unemployment rate); $\delta_{s}$ are state fixed effects; $\nu_{t}$ are year fixed effects; $\gamma_{s t}$ are state-specific linear trends (at the election level); and $\epsilon_{s t}$ is an error. We run these regressions separately for different types of elections (parliamentary, state, and presidential), and allow for arbitrary within-state correlation of the errors by clustering our standard errors at the state level. Given the small number of clusters, our standard errors might be inconsistently estimated (Bertrand et al., 2004). Following Cameron et al. (2008), we also report wild-bootstrap p-values. ${ }^{28}$

In these specifications, our "treatment group" are statesXelectoral periods subject to $\mathrm{CV}$, while the "control group" comprises those in which voting is voluntary. At any given period in time, we compare states under CV vs VV (leveraging the time fixed effects), and at the same time, we make within-state comparisons, comparing electoral terms with and without CV (using state fixed effects). Using state level data, we analyze the effect of CV on: (i) turnout and valid ballots; (ii) left/right vote shares, number of parties, vote shares and margin of victory of the winning party; and (iii) government expenditures in social services, administration, and infrastructure. For (i) and (ii), the analysis unit is stateXelection; when

\footnotetext{
${ }^{28}$ We calculated the wild-bootstrap p-values using the cgmwildboot program created by Judson Caskey, and imposed the null hypothesis, as recommended by Cameron et al. (2008).
} 
analyzing the impact of $\mathrm{CV}$ on expenditures, the analysis unit is a stateXyear. ${ }^{29,30}$

\subsection{Turnout and Invalid Votes}

Even with weak enforcement, as is the case for Austria, CV can affect turnout through the signaling value of enacting a law, as argued in Funk (2007). Panel A in Table 3 shows the effects of CV on turnout within and across Austrian states in the 1949-2010 period. The introduction of CV causes statistically and economically significant increases in turnout in parliamentary, state, and presidential elections.

When independently considering each type of election, we find that CV increases turnout by 6.5 percentage points in parliamentary elections, by 17.2 percentage points in state elections, and by 9.5 percentage points in presidential elections. However, we gain additional power by pooling all types of elections together, as doing so allows more precise estimation of the year and state fixed effects. In column 4 of Panel A in Table 3, we report the independent effect of $\mathrm{CV}$ on each type of election using the pooled dataset (our preferred specification). CV now increases turnout by $6.6,8.1$, and 9.1 percentage points for parliamentary, state, and presidential elections, respectively. Note that these results show slightly lower point estimates than in the previous regressions, and this is particularly the case for state elections, for which we have a smaller sample size. The results are highly significant based on standard errors clustered by state (in parentheses) or based on wild bootstrap p-values (in brackets). ${ }^{31}$

CV can increase turnout by drawing uninterested voters, or those who might not be

\footnotetext{
${ }^{29}$ We assume that government spending in the years within a particular electoral period depends on whether voting was compulsory in the previous election. Thus, if elections takes place in years $t$ and $t+4$, we consider that expenditures in the years spanning from $t+1$ to $t+5$ are a function of whether voting was compulsory in $t$. This is a plausible assumption, since most of the elections in our sample occurred in the last trimester of the year, thus policies implemented by the elected government would only start having an effect on spending decisions in subsequent years.

${ }^{30}$ In the case of (i), in addition to running separate regressions for each type of election, we also run a pooled regressions using all elections. Besides the reduced form analysis presented above, we also analyze the effect of (exogenous) changes in turnout on (ii) and (iii) using an instrumental variable approach in which $C V_{s t}$ is used as an instrument for voter turnout. These results are shown in the Appendix.

${ }^{31}$ Note that the wild bootstrap procedure does not deliver bootstrapped standard errors, but rather p-values. The p-values found using the clustered standard errors and the wild bootstrap procedure are generally similar in most cases. Throughout the paper, for ease of exposition, our interpretation of confidence intervals is based on the clustered standard errors.
} 
familiar with the voting process. If this is the case, we might expect the proportion of invalid ballots to rise. As shown in Panel B of Table 3, the increase in turnout from CV is paired with a statistically significant increase in invalid votes. In elections without CV, the share of invalid votes ranges between $1.5 \%$ and $3.8 \%$. Based on the results in the preferred specification (column 4), CV increases the share of invalid votes by 0.9-1.8 percentage points, depending on the type of election. Even though the increase in turnout associated with CV is also conducive to a higher proportion of invalid votes, there is certainly not a one-to-one relation. That is, for every 10 people who are driven to vote due to CV, only $1.5-3$ of them issue an invalid ballot, while the others correctly vote for a party or candidate. Hence, an increase in turnout of this magnitude could very well result in a shift in election results and public policies. ${ }^{32}$

\subsection{Public Spending}

An increase in participation rates could potentially affect government spending in several ways. Depending on the competencies of the elected body analyzed, it could increase the overall size of the budget by pushing the local government or local parliamentarians to negotiate larger budgets from the federal government, or by increasing taxation. Alternatively, if preferences for public goods in the participating electorate are now different, the government might also change the distribution of public spending, keeping the size of the overall budget constant, but shifting it between sectors.

In the Austrian context, we might expect increases in turnout in different elections to affect different parts of the budgetary process. As discussed in Section 2.1, given the ceremonial role of the federal president, we don't expect to see effects of CV in presidential elections on spending - as a placebo test, we run regressions estimating the effect of CV in presidential elections on fiscal behavior at the state level, and as expected, we do not find any effects (Appendix Table A.4). On the other hand, the national parliament decides on the resources that

\footnotetext{
${ }^{32}$ Given that the analysis of the effects of CV on fiscal behavior is performed only for those years for which expenditure data is available (1979-2010), we re-run the analysis from Table 3 on a comparable sample in Appendix table A.3. The results shown for turnout and invalid votes are comparable to the ones for 1949-2012.
} 
each state government gets, so if anything, we should observe changes in the parliamentarian's constituents affecting the state's total budget, but not its sectoral distribution. Finally, given that state parliaments nominate a share of the members of the Federal Council, changes in the state parliamentarian's incentives could affect the national distribution of the budget between states. Likewise, state parliaments are in charge of preparing the state's budget, and thus laws that affect this level of government should have an effect on the sectoral distribution of state spending. In this section, we turn our attention to the effects of CV on fiscal policy at the state level.

In the subsequent analysis, we study total state expenditures, as well as their composition: administrative, welfare, and infrastructure expenditures. For each spending category, we independently analyze three different measures of fiscal policy, which are intended to test the different mechanisms described above: (i) the log levels, (ii) the log per-capita, and (iii) as a percentage of the total budget. We use a similar estimation framework as in Section 4.1.

Table 4 shows no consistent evidence of CV affecting the amount or composition of public spending. Most estimated coefficients are quite close to zero, and the clustered standard errors as well as the wild-bootstrap p-values indicate that there is no significant relationship between $\mathrm{CV}$ and total budget or its composition. Across the 12 regressions in Panel A of Table 4, the estimated coefficients are sometimes positive and sometimes negative, but small in magnitude. They are also relatively precise. For example, the estimated coefficient in column 1 on total spending corresponds to a $95 \%$ confidence interval of $[-0.009,0.071]$, meaning we can reject that CV decreases total spending in more than $0.9 \%$ or that it increases it by more than about 7.1\%. Similarly, the point estimates on administrative, welfare, and infrastructure spending are relatively close to zero, at $0.6 \%, 3.5 \%$, and $6.6 \%$, respectively. ${ }^{33}$ In contrast, electronic voting in Brazil (Fujiwara, 2015, p.452) and US women's suffrage (Miller, 2008, p.1289) are

\footnotetext{
${ }^{33}$ These zero results are also qualitatively robust under an instrumental variable approach, where we estimate the effect of turnout (instrumented by CV) on expenditures (see Appendix Table A.7). Similarly, we run the regressions for the most disaggregated expenditure categories available, and they are shown in Tables A.5 and A.6 in the Appendix. All results show coefficients very close to zero, showing our results are robust to alternative groupings of the expenditure subcategories. However, given the granular level of the data, some confidence intervals are relatively large (e.g., for finance and service expenditures). If we exclude both subcategories from our main expenditure classifications, we continue to find null effects.
} 
estimated to have each raised health spending by about one-third.

Our result on public spending contrast with those of Hodler et al. (2015) and Godefroy and Henry (2015). Consistent with a model where decreases in voting costs increase the share of voters who are uninformed, Hodler et al. (2015) find that Swiss postal voting decreased welfare spending by 4-7 percent and business taxation by 3-7 percent. Why might our result differ? First, there are various political differences between Switzerland and Austria, including that Switzerland has much lower turnout (though other levels of political involvement and interest do not seem so different). For example, following the idea of the model of Hodler et al. (2015), it could be that there are few "impressionable" voters for politicians to take advantage of in Austria, and this could limit whether there are impacts on spending. ${ }^{34}$ Second, postal voting and CV may have different impacts on a political system. It is not clear that the population of voters who would respond to $\mathrm{CV}$ are the same as those would respond to postal voting. Even if both populations seem more uninformed on average, they may differ on unobservables. We note, though, that these explanations are speculative and cannot fully resolve why there are differences across papers. Further research is needed.

Godefroy and Henry (2015) show that a decrease in turnout in French cities due to more digestive infections leads to higher infrastructure expenditure, and they argue that this is due to the selection of better qualified politicians. In our paper, it is difficult to test this hypothesis directly because we do not observe any information on the quality of politicians (such as data on politician "cost-effectiveness"). In addition, in contrast to us, Godefroy and Henry (2015) study unanticipated, unknown-in-advance shocks to voting cost.

\subsection{Robustness Checks}

The identification assumption in our main regressions is that CV is uncorrelated with unobserved time-varying state characteristics once we've controlled for time invariant, state-specific

\footnotetext{
${ }^{34}$ There are a number of other potentially significant political differences between Switzerland and Austria, including that Austria is more linguistically homogeneous and that Switzerland and Austria have different historical experiences and traditions with democracy. Following Hodler et al. (2015), Switzerland and Austria could also conceivably differ in voter preferences regarding private consumption and government spending.
} 
factors, as well as year-specific, state invariant factors, and partialled out state-specific linear time trends. For example, if conservative states are more likely to support CV, this should be absorbed by our state fixed effects. On the other hand, if there is a national push for abolishing these types of laws (e.g., in 1982), this would be captured by the year fixed effects. One threat to our identification assumption is that, even though some of the changes in CV laws were issued by the federal parliament (e.g., the 1992 repeal of CV in parliamentary elections), and thus are unlikely to respond to state-specific political dynamics, others changes were issued at the state level, and these decisions might be related to voting trends. As in any difference-in-difference model, this is the same as assuming that, conditional on the set of observables and fixed effects, the trends in voting, political competition, and expenditures in states in which CV was introduced were the same as in states where voluntary voting was in place; if the new voting regime had not been enacted, e.g., they have parallel trends in the pre-treatment period.

The parallel trends assumption would be violated if the states most likely to implement CV were those in which turnout was downward trending. In this case, an estimation relying on simple fixed effect will understate the effect of CV laws. Similarly, state governments might find it easier to enact CV laws when turnout is trending upward, since enforcement costs will be lower in these states. In this case, a fixed effects model would overestimate the results. The inclusion of state-specific time trends controls for any linear trends in our outcome variables, and thus partially addresses these concerns, but further tests are needed.

As mentioned in Section 2.2, in our study period there is one change in CV laws that is unrelated to any state-year specific characteristic, namely, the one introduced by the federal government in 1992. ${ }^{35}$ This Federal Constitution amendment withdrew the prerogative of establishing mandatory voting in the national parliament elections from the states. Effectively, while some states already had voluntary voting in parliamentary elections, others (Vorarlberg, Styria, Tyrol and Carinthia) were forced to adopt it. Figure 4 shows the evolution of turnout,

\footnotetext{
${ }^{35}$ Ferwerda (2014) uses this federal change in legislation to explore changes in party vote shares, and argues that, given that it was issued at the federal level, it is independent to the political dynamics at the local level.
} 
invalid votes, and total, administrative, welfare, and infrastructure expenditures in the same analysis period (1986-2011), for states that never had CV and those that were mandated to eliminate it in 1992. States that had CV before 1992 had higher turnout and more invalid ballots, but importantly, before $\mathrm{CV}$ is abolished, the trends in these variables run parallel to the ones in states that did not have CV before 1992. Similarly, in our four expenditure variables, for which we do not observe an effect of the elimination of $\mathrm{CV}$, the trends for both types of states run parallel during the whole study period. ${ }^{36}$

To further alleviate the concerns that CV laws might have been introduced responding to changes in our dependent variables of interest, in Table A.9 we include leads and lags of our main independent variable in our preferred specification for turnout and invalid votes. If it were the case that CV laws responded to changes in turnout, we would expect turnout in period $t$ to be correlated to either $\mathrm{CV}$ in $t+1$ or $\mathrm{CV}$ in $t-1$. The results show that, besides the contemporaneous effect of $\mathrm{CV}$ on turnout and invalid votes, the introduction of CV in the previous election or next electoral period has no effect on our variables of interest. The estimated effects for the three types of elections show a "zero" of the lags and leads of our independent variable, i.e., there were no pre-trends, or anticipation effects. ${ }^{37}$ A potential concern is that authorities anticipate the introduction/repeal of CV laws and alter the level or composition of public spending before the law change takes place. If this were the case, we would observe a correlation between public spending in year $t$ and CV in $t+1$. Alternatively, any delays in the reaction of public spending to changes in CV laws would lead to a correlation between $\mathrm{CV}$ in $t-1$ and public spending in year $t$, which would not be captured in our baseline specification. As seen in Table A.10, spending is uncorrelated with CV in the past, current, or future electoral period for all types of elections.

Together, Figure 4 and Tables A.8-A.10 provide evidence supporting the parallel trend

\footnotetext{
${ }^{36}$ We also perform a difference-in-difference regression limiting our sample to the parliamentary elections in the electoral periods between 1986 and 2011. The magnitude and statistical significance of the results is remarkably similar to those shown in Tables 3 and 4, suggesting that any other changes in CV (besides the 1992 one) are unlikely to be correlated with trends in the main dependent variables. For further details turn to Table A.8 and Appendix C.

${ }^{37}$ One exception is the surprising significance of the coefficient of the lead of CV for presidential elections.
} 
assumption, and help rule out potential reverse causation between turnout and CV. As an additional robustness check, in Appendix C, we discuss heterogeneity in our spending (and turnout) results according to levels of turnout in different states.

\section{Understanding the "Null Effect" on Policy Outcomes}

How could it be that CV had sizable impacts on turnout, increasing the number of valid votes, but did not affect policy outcomes? One potential explanation for these results is that the political choices of people who turn out because of CV are, on average, similar to the ones of people who would have voted even in the absence of CV. Another explanation is that median voter preferences may have changed, potentially leading to changes in electoral outcomes, but government spending still doesn't change for some other reason (e.g., commitment or agency issues). ${ }^{38}$

Besides exploring electoral outcomes, we also attempt to shed light on identifying the marginal voters affected by CV. If new voters do not make significantly different political choices compared to those voters who participate even under voluntary voting, we would not expect the identity of the median voter to change, and hence shouldn't observe changes in policies. Several recent studies analyze large increases in turnout due to de jure or de facto enfranchisement of specific groups of the electorate (e.g., women in Miller (2008), the poor and illiterate in Fujiwara (2015), and African-Americans in Naidu (2012)); unlike these studies, we do not necessarily have a strong prior that people who vote because of CV make significantly different political choices than those who vote even when voting is voluntary.

\footnotetext{
${ }^{38}$ For example, in citizen candidate models (Besley and Coate, 1997; Osborne and Silvinski, 1996), politicians may implement preferred policies that may differ from those of the median voter. In empirical work, Lee et al. (2004) (building on the model of Alesina (1988)) show that exogenous changes in party electoral strength do not affect the voting patterns of US congressmen.
} 


\subsection{Electoral Outcomes}

Table 5 examines whether CV affects various electoral outcomes. We estimate a similar regression as in Section 4.1, but use as dependent variables the percentage of votes to the left or right wing parties, the number of parties, the share of votes of the winning party and its margin of victory (i.e., the difference in vote share between the winning party and the runner-up). For both parliamentary and state elections, CV does not affect the share of votes going to the right or left parties. ${ }^{39}$ Further, there is no response from the political supply: the number of parties remains constant at about 6.9 and 6 for parliamentary and state elections, respectively. Finally, the party that wins the election does not receive a significantly different proportion of votes under $\mathrm{CV}$, compared to states and elections in which voting is voluntary. ${ }^{40}$

In a related paper, Ferwerda (2014) exploits the 1992 constitutional change to analyze the effects of political participation on electoral results. Using municipality level data from the 1990 and 1994 elections (before and after the change), he finds statistically significant but fairly small effects on the vote share for minor parties, as well as an increase in votes for the SPÖ (left wing party). The magnitude of the results found are consistent with our findings, particularly with the magnitude of the coefficients found when restricting our analysis period (Appendix Table A.11). However, the focus of our paper is on explaining the potential effects of $\mathrm{CV}$ on fiscal behavior, and even though there might be an (insignificant) effect on party vote shares, they are small enough that they do not affect the election outcomes.

Overall, Table 5 suggests that CV does not affect party vote shares, the number of parties, or margin of victory. If the Austrian political process follows the workings of a citizen-candidate model, the fact that the increase in turnout was not paired with changes in electoral outcomes is consistent with a null impact of $\mathrm{CV}$ on public expenditures.

\footnotetext{
${ }^{39}$ We do not perform these regressions for presidential elections because parties do not run as separate entities in those races. Additionally, we find no effects on individual party vote shares or voter polarization. See Appendix C for details. Somewhat relatedly in the literature, Martinez and Gill (2005) examine how turnout affects Democrat vote share in US presidential elections.

${ }^{40}$ Results for the 1979-2010 period shown in Appendix Table A.11 are comparable to those in Table 5. We find relatively larger point estimates for the effects of $\mathrm{CV}$ on party vote shares, but they are not statistically significant. Only for the case of votes for the left wing parties in parliamentary elections do we find a statistically significant impact of CV; however, the effect of $\mathrm{CV}$ in this case is small.
} 


\subsection{Composition of the Electorate}

We use individual data from two rounds of the ASS (1986 and 2003) to examine what type of voters were most affected by CV. The goal is to better understand the mechanisms underlying our main results. We have information on turnout in the previous parliamentary election (1983 and 2002), and exploit within and between state variation in CV introduced by the federal abolition of CV between the surveys (in 1992). While no states had CV in the 2002 parliamentary election, 3 states (Styria, Tyrol, and Vorarlberg) had it in the 1983 elections. Our dependent variable is whether an individual voted in the previous parliamentary election, and our main regressor is a dummy for whether voting was compulsory in that election in the state where the respondent lives. We control for a set of individual covariates, as well as state and survey year fixed effects. ${ }^{41}$ To examine what type of voters are more likely to respond to $\mathrm{CV}$, we interact $\mathrm{CV}$ with various individual characteristics. ${ }^{42}$

Table 6 shows 8 separate regressions. In the left panel, we observe that impacts of compulsory voting seem to be larger among females, among those with a vocational middle school degree, and to a certain extent among those in the lower two income quartiles. ${ }^{43}$ In this table, the wild bootstrap p-values are larger than the implied p-values from the clustered standard errors, making the inference here more suggestive. In the right panel, we observe that the impact of compulsory voting is larger among people who are not party members, who are not informed (proxied by newspaper reading), who declare themselves uninterested in politics, and who report no party preference. For example, the coefficient of 0.138 in

\footnotetext{
${ }^{41}$ Controls included in all regressions in this section include: age, age squared, gender, educational attainment, parents' education, working status, household size, community size, party preferences, party membership, interest in politics, and information acquisition (read newspaper regularly).

${ }^{42}$ Although the ASS asks about which party respondents voted for, we do not analyze this outcome because $17 \%$ of our sample didn't answer this question, and attrition is differential along individuals' self-reported political preferences.

${ }^{43}$ In the first regression, we examine the impact on CV on turnout without interaction effects. CV increases turnout by 4.2 percentage points, slightly lower than the effect shown with aggregate, state-level data. We must bear in mind however that these regressions rely on self-reported data, which might measure turnout with error. A standard concern could be that people might lie about whether they voted. We take comfort from the fact that the self-reported voting shares of $94 \%$ and $82 \%$ in 1983 and 2002 are relatively close to the actual voting shares in our data (93\% and $85 \%$, respectively) suggesting that misrepresentation is unlikely to be a big issue in our data.
} 
regression 8 indicates that $\mathrm{CV}$ increases turnout by 13.8 percentage points among individuals with no party preference. In contrast, for individuals who declare a party preference toward the main left or right parties in Austria, CV increases turnout by 2-3 percentage points.

Although CV may have affected the gender, educational attainment, and income of the median voter, our results indicate that it may not have shifted the median voter's political preferences. If those induced to vote by $\mathrm{CV}$ don't have strong political views, then such voters may not necessarily vote differently from the median voter in elections without CV. If the choices of the average voter are not shaped by CV, it would not be surprising if $\mathrm{CV}$ failed to affect what policies are implemented or what party wins. These results may also be consistent with a citizen candidate framework in which significant changes in the electorate are not necessarily accompanied by changes in policy outcomes. Unfortunately, we do not have enough data to test which of these two frameworks are more suited to explain the results observed.

\section{External Validity and Conclusion}

Although compulsory voting $(\mathrm{CV})$ is often viewed as a way to foster voter turnout and consequently improve the representativeness of political processes, relatively little is known about how CV causally affects voter participation and, in particular, how it affects economic policy. We analyze these impacts by leveraging quasi-experimental variation in CV laws across Austria's nine states. We find that CV increased turnout from roughly $80 \%$ to $90 \%$. This occurred even though penalties for not voting were rarely enforced. However, in our main results, the increase in turnout did not affect state-level spending (either in levels or shares of sectoral spending) or electoral outcomes. Effects of CV seem larger among individuals who are uninterested in politics, do not have strong political views, and are relatively uninformed (with informedness proxied by newspaper reading).

We view our results as consistent with a story where voters swayed to vote by CV do not cast different votes from those who vote regardless of the law. Our results may also be 
consistent with other explanations (e.g., citizen candidate models) where politicians implement policies that may not correspond to those preferred by the median voter. Ultimately, it is difficult to say definitively what theoretical mechanism explains our results. Our contribution, though, is to provide causal evidence (previously lacking) that CV laws need not significantly affect government spending. We believe this is important evidence for the policy debate regarding $\mathrm{CV}$.

Overall, our results complement the literature documenting that extension of the voting franchise to specific population groups impacts policy. Our study suggests that policies aimed at increasing turnout (e.g., get-out-the-vote campaigns) need not necessarily affect public spending, and this seems particularly the case if these policies do not increase turnout among voters with specific policy preferences.

Our results are specific to Austria, so it's important to consider to what extent we think the results would extrapolate to other countries. As discussed earlier in Section 3.1, Austria has had relatively high turnout and political involvement even when CV was not in place, at least relative to the US and the OECD averages. At the same time, however, there are a sizable number of countries (e.g., Germany, the Scandinavian countries, and others) that share these features, particularly in Europe. Thus, we believe our findings may be relevant for these countries and other advanced democracies where reforms to increase political participation (such as CV laws) are being evaluated.

How might our results extrapolate for countries with lower levels of political involvement? In terms of turnout, one might imagine that countries with low initial turnout levels might experience even greater turnout increases (in absolute percentage levels) as a result of CV compared to countries like Austria with traditionally high turnout. Thus, our turnout findings could form a "lower bound" for impacts for reforms implemented in countries with low turnout. ${ }^{44}$ Turning to government spending, as observed earlier in the paper, many countries without CV (such as the US) experience significant disparities in turnout along socio-economic

\footnotetext{
${ }^{44}$ However, one can also imagine situations where CV laws have smaller effects. For example, countries with low turnout may be reflective of citizens being generally distrustful of government and authority. Such characteristics could lead to CV laws having less of an effect.
} 
lines, which are also correlated with levels of political interest. For Austria, our results suggest that CV induces low-interest or low-knowledge voters to participate. For countries with low initial turnout, while it is possible that voters induced to participate because of CV would have low interest in politics, it is also possible that a broader set of voters would be affected. This might cause CV to actually have a significant impact on government spending. However, as noted by Hodler et al. (2015), changes in voting costs could affect government spending in either direction, and it is challenging to make confident empirical predictions about possible impacts of CV in a setting very different from Austria. Thus, we urge significant caution in assessing the relevance of our results for countries like the US where turnout is much lower than in Austria.

Beyond political involvement, there are a host of other factors that may affect how CV affects government spending including whether there is a presidential or parliamentary system, and whether the population is relatively ethnically heterogeneous or homogenous. While we do not have strong priors on how such factors would influence the impact of CV, we cannot rule out that they may be at play. While our results provide the first quasi-experimental evidence on how CV affects government spending, they are certainly not the last word. We look forward to future research on how CV affects government spending, hopefully using data from additional countries.

\section{References}

Alesina, Alberto, "Credibility and Policy Convergence in a Two-Party System with Rational Voters," American Economic Review, 1988, 78 (4), 796-805.

Bertrand, Marianne, Esther Duflo, and Sendhil Mullainathan, "How Much Should We Trust Differences-in-Differences Estimates?," Quarterly Journal of Economics, 2004, $119(1), 249-275$. 
Besley, Timothy and Stephen Coate, "An Economic Model of Representative Democracy," Quarterly Journal of Economics, 1997, 112 (1), 85-114.

Bischof, Günter and Fritz Plasser, The changing Austrian voter, Vol. 16, Transaction Publishers, 2008.

Blöndal, Jón R. and Daniel Bergvall, "Budgeting in Austria," OECD Journal on Budgeting, 2007, 7, 1-37.

Börgers, Tilman, "Costly Voting," American Economic Review, 2004, 94 (1), 57-66.

Brady, Henry and John McNulty, "Turning Out the Vote: The Costs of Finding and Getting to the Polling Place," American Political Science Review, 2011, 5 (1), 1-20.

Cameron, A. Colin, Jonah B. Gelbach, and Douglas L. Miller, "Bootstrap-Based Improvements for Inference with Clustered Errors," The Review of Economics and Statistics, May 2008, 90 (3), 414-427.

Cascio, Elizabeth U. and Ebonya Washington, "Valuing the Vote: The Redistribution of Voting Rights and State Funds Following the Voting Rights Act of 1965," The Quarterly Journal of Economics, 2014, 129 (1), 376-433.

Chong, Alberto and Mauricio Olivera, "Does Compulsory Voting Help Equalize Incomes?," Economics and Politics, 2008, 20 (3), 391-415.

Enikolopov, Ruben, Maria Petrova, and Ekaterina Zhuravskaya, "Media and Political Persuasion: Evidence from Russia," American Economic Review, 2010, 111 (7), 3253-3285.

Farber, Henry, "Increasing Voter Turnout: Is Democracy Day the Answer?," 2009. Princeton University Working Paper 546.

Ferwerda, Jeremy, "Electoral Consequences of Declining Participation: A Natural Experiment in Austria," Electoral Studies, 2014, 35, 242-252. 
Fowler, Anthony, "Electoral and Political Consequences of Voter Turnout: Evidence from Compulsory Voting in Australia," Quarterly Journal of Political Science, 2013, 8 (2), 159182.

Fraga, Bernard and Eitan Hersh, "Voting Costs and Voter Turnout in Competitive Elections," Quarterly Journal of Political Science, 2010, 5, 339-356.

Fujiwara, Thomas, "Voting Technology, Political Responsiveness, and Infant Health: Evidence from Brazil," Econometrica, 2015, 83 (2), 423-464.

Funk, Patricia, "Is there an Expressive Function of Law? An Empirical Analysis of Voting Laws with Symbolic Fines," American Law and Economics Review, 2007, 9 (2), 135-159.

Gallego, Aina, "Unequal Political Participation in Europe," International Journal of Sociology, 2007, 37 (4), 10-25.

Gavazza, Alessandro, Mattia Nardotto, and Tommaso Valletti, "Internet and Politics: Evidence from UK Local Elections and Local Government Policies," 2014.

Gentzkow, Matthew, "Television and Voter Turnout," Quarterly Journal of Economics, 2006, $121(3), 931-972$.

_, Jesse M. Shapiro, and Michael Sinkinson, "The Effect of Newspaper Entry and Exit on Electoral Politics," American Economic Review, 2011, 101 (7), 931-972.

Gerber, Alan S and Donald P Green, Field experiments: Design, analysis, and interpretation, WW Norton, 2012.

Godefroy, Rafael and Emeric Henry, "Voter turnout, politicians' quality and public expenditures," 2015. Mimeo.

Gomez, Brad, Thomas Hansford, and George Krause, "The Republicans Should Pray for Rain: Weather, Turnout, and Voting in U.S. Presidential Elections," Journal of Politics, 2007, 69, 649-663. 
Gradstein, Mark and Branko Milanovic, "Does Libert = Egalit? A Survey of the Empirical Links between Democracy and Inequality with Some Evidence on the Transition Economies," Journal of Economic Surveys, 2004, 18 (4), 515-537.

Haller, Max, Kurt Holm, and R. Oldenbourg Verlag, Werthaltungen und Lebensformen in Österreich. Ergebnisse des Sozialen Survey 1986, Munich: R. Oldenbourg Verlag, 1987.

_, Wolfgang Schulz, and Alfred Grausgruber, Österreich zur Jahrhundertwende. Gesellschaftliche Werthaltungen und Lebensqualität 19862004, Wiesbaden: Verlag für Sozialwissenschaften, 2005.

Hansford, Thomas and Brad Gomez, "Estimating the Electoral Effects of Voter Turnout," American Political Science Review, 2010, 104 (2), 268-288.

Herrera, Helios, Massimo Morelli, and Thomas Palfrey, "Turnout and power sharing," The Economic Journal, 2014, 124 (574), F131-F162.

Hinnerich, Björn Tyrefors and Per Pettersson-Lidbom, "Democracy, Redistribution, and Political Participation: Evidence From Sweden 1919-1938," Econometrica, 2014, 82 (3), 961-993.

Hirczy, Wolfgang, "The Impact of Mandatory Voting Laws on Turnout: A QuasiExperimental Approach," Electoral Studies, 1994, 13 (1), 64-76.

Hodler, Roland, Simon Luechinger, and Alois Stutzer, "The Effects of Voting Costs on the Democratic Process and Public Finances," American Economic Journal: Economic Policy, 2015, 7 (1), 141-171.

Husted, Thomas A. and Lawrence W. Kenny, "The Effect of the Expansion of the Voting Franchise on the Size of Government," Journal of Political Economy, 1997, 105, $54-82$. 
Knack, Steve, "Does Rain Help Republicans? Theory and Evidence on Turnout and Vote," Public Choice, 1994, 79, 187-209.

Krasa, Stefan and Matthias K. Polborn, "Is mandatory voting better than voluntary voting?," Games and Economic Behavior, 2009, 66 (1), 275-291.

Krishna, Vijay and John Morgan, "Overcoming Ideological Bias in Elections," Journal of Political Economy, 2011, 119 (2), 183-211.

Lee, David S., Enrico Moretti, and Matthew J. Butler, "Do Voters Affect Or Elect Policies? Evidence from the U. S. House," Quarterly Journal of Economics, 2004, 119 (3), 807-859.

Leon, Fernanda Leite Lopez De and Renatai Rizzi, "A Test for the Rational Ignorance Hypothesis: Evidence from a Natural Experiment in Brazil," American Economic Journal: Economic Policy, 2014, 6 (4), 380-398.

León, Gianmarco, "Turnout, Political Preferences and Information: Experimental Evidence from Peru," 2015. BREAD Working Paper 376.

Lijphart, Arend, "Unequal Participation: Democracy's Unresolved Dilemma," American Political Science Review, 1997, 91 (1), 1-14.

Linz, Juan, Alfred Stephan, and Yogendra Yadav, Democracy and Diversity, New Delhi: Oxford University Press, 2007.

Martinez, Michael D and Jeff Gill, "The effects of turnout on partisan outcomes in US presidential elections 1960-2000," Journal of Politics, 2005, 67 (4), 1248-1274.

Meltzer, Allan H. and Scott F. Richard, "A Rational Theory of the Size of Government," Journal of Political Economy, 1981, 89 (5), 914-927.

Miller, Grant, "Women's Sufrage, Political Responsiveness, and Child Survival in American History," The Quarterly Journal of Economics, 2008, 123 (3), 1287-1327. 
Naidu, Suresh, "Suffrage, Schooling, and Sorting in the Post-Bellum U.S. South," 2012. NBER Working Paper18129.

Osborne, Martin J. and Al Silvinski, "A Model of Political Competition with CitizenCandidates," The Quarterly Journal of Economics, 1996, 111 (01), 65-96.

Persson, Torsten and Guido Tabellini, Political Economics: Explaining Economic Policy, Cambridge MA: MIT Press, 2000.

Rodriguez, F. C, "Does Distributional Skewness Lead to Redistribution? Evidence from the United States," Economics and Politics, 1999, 11, 171-199.

Shineman, Victoria, "Isolating the Effect of Compulsory Voting Laws on Political Sophistication: Exploiting Intra-National Variation in Mandatory Voting Laws Between the Austrian Provinces," 2014.

Stromberg, David, "Radio's Impact on Public Spending," Quarterly Journal of Economics, 2004, $119(1), 589-621$.

Timpone, Richard J., "Structure, Behavior, and Voter Turnout in the United States," The American Political Science Review, 1998, 92 (1), 145-158.

_, "Demokratische Beteiligung und Staatsausgaben: Die Auswirkungen des Frauenstimmrechts," Swiss Journal of Economics and Statistics, 2005, 141 (4), 617-650.

Washington, Ebonya, "How Black Candidates Affect Voter Turnout," Quarterly Journal of Economics, 2006, 121 (3), 979-998. 


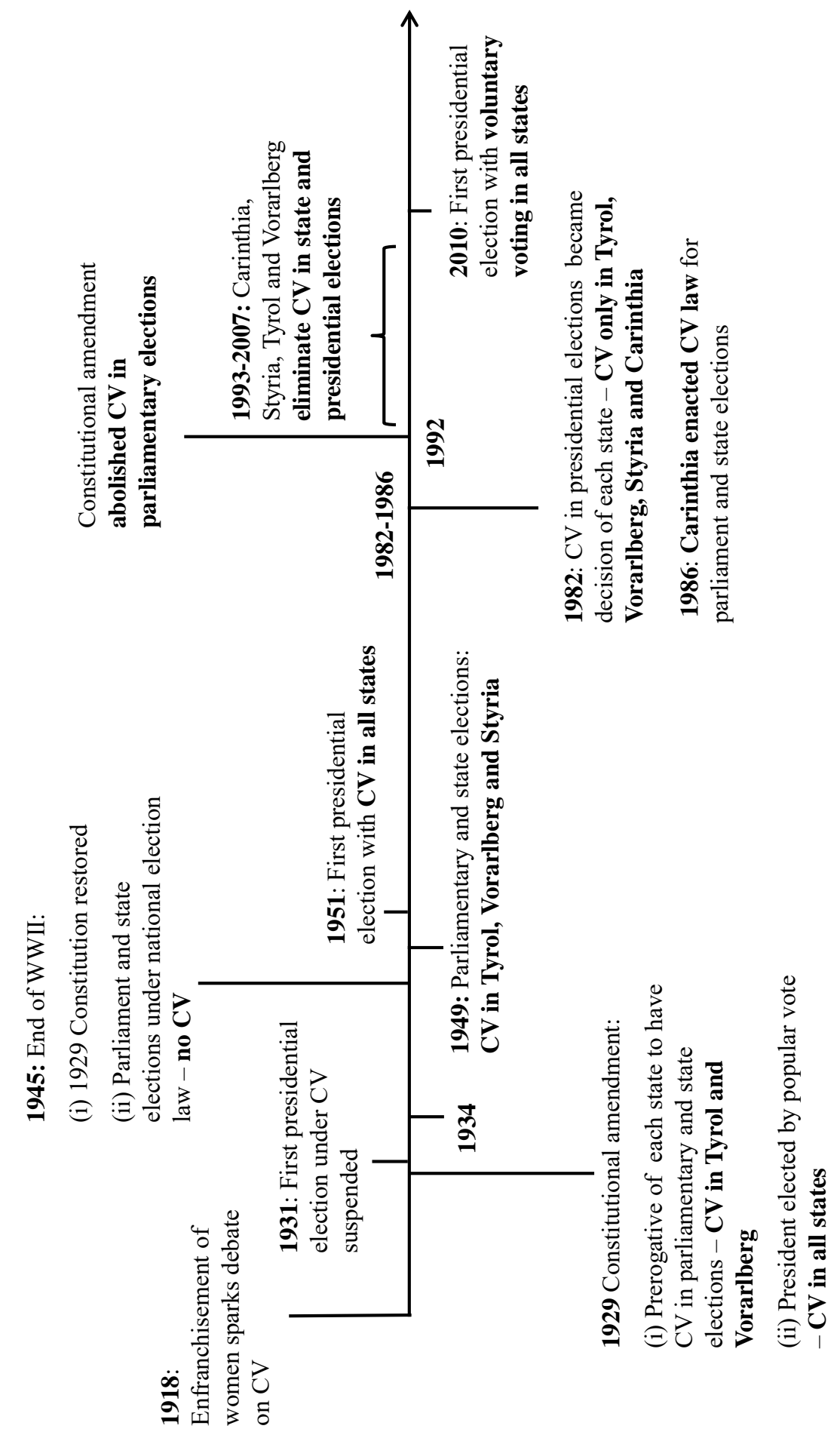




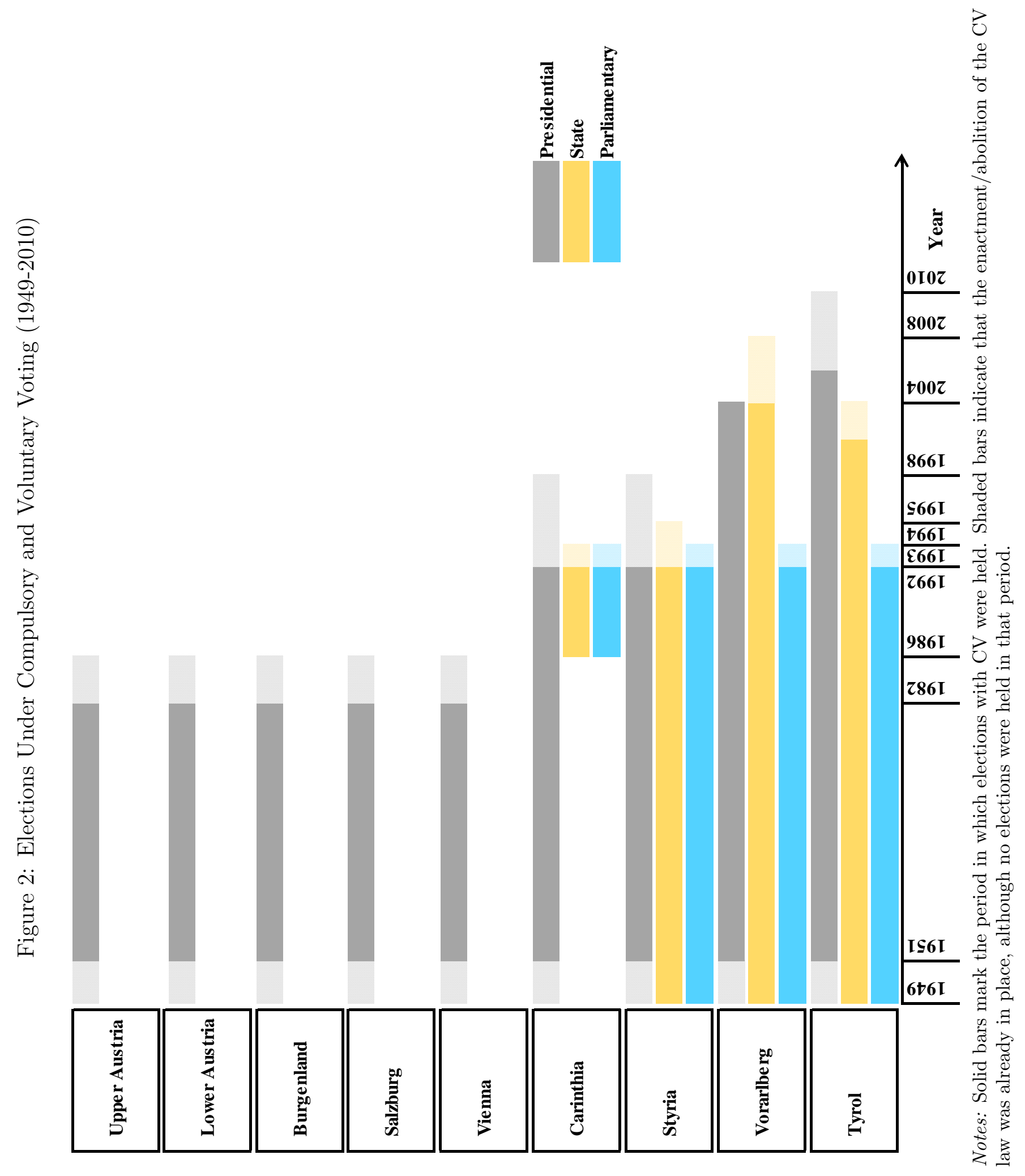



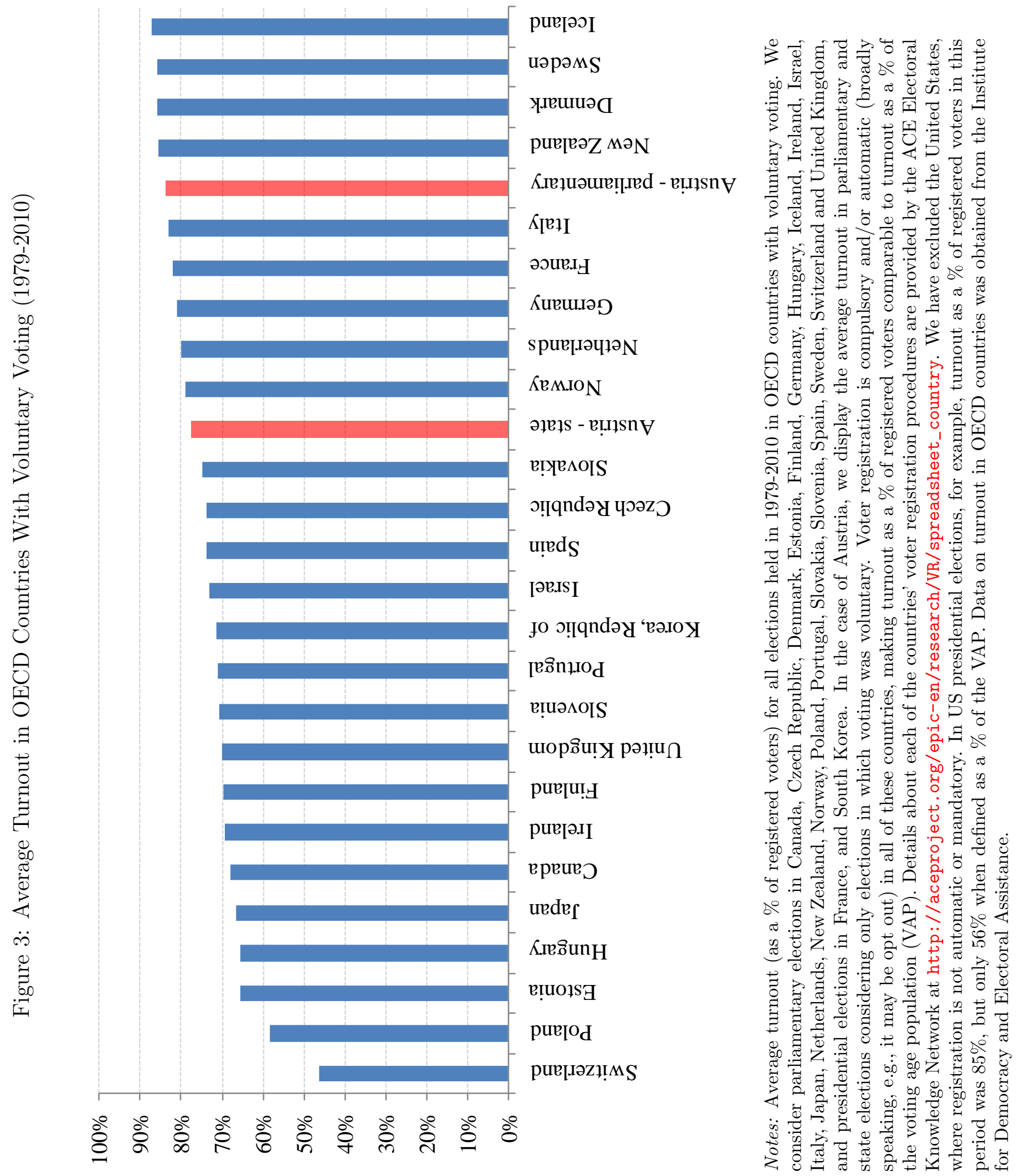

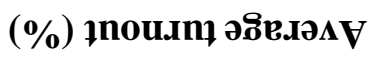




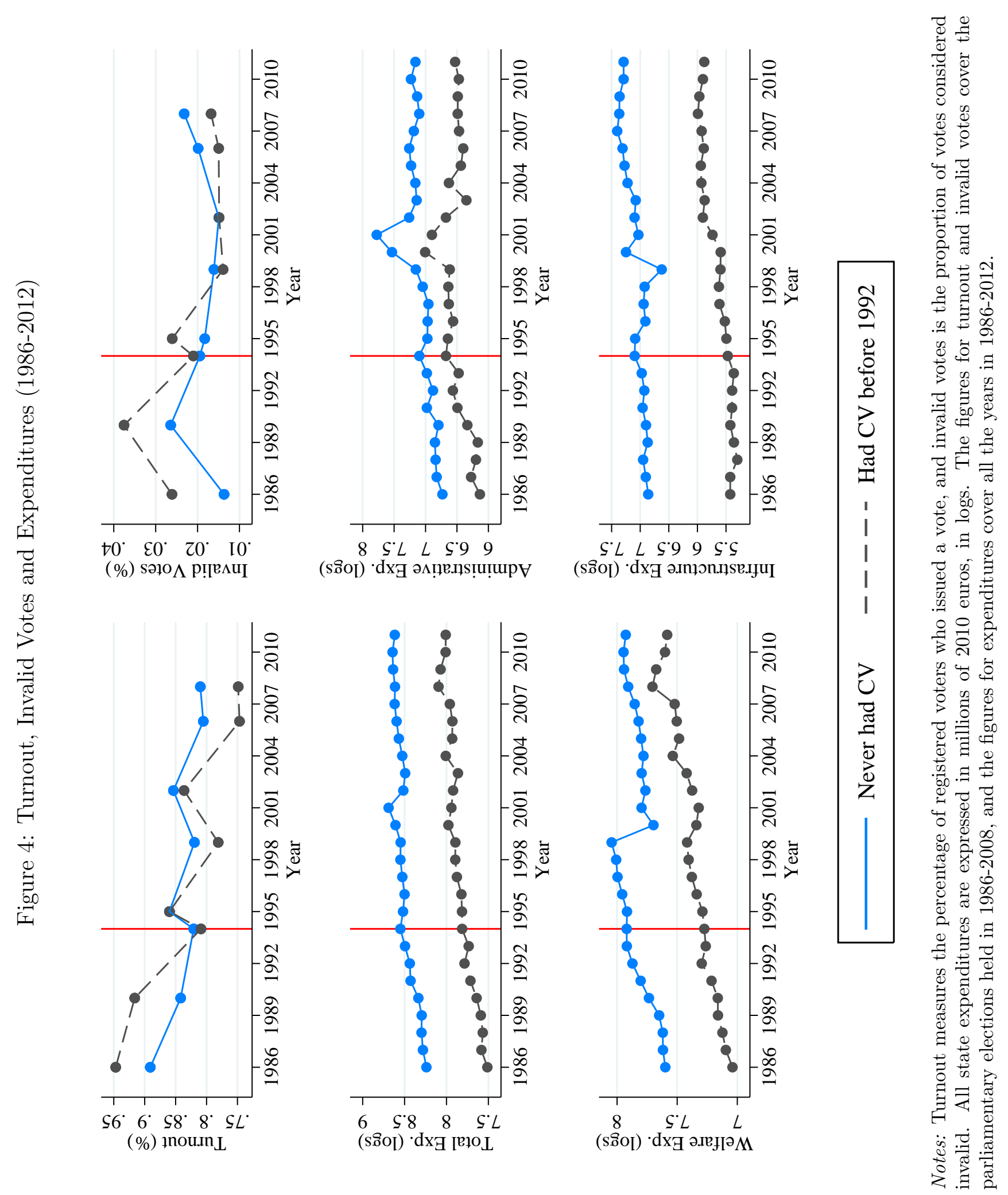


Table 1: Summary Statistics (1949-2012)

\begin{tabular}{|c|c|c|c|c|c|}
\hline & Observations & Mean & Std. Dev & Min & Max \\
\hline \multicolumn{6}{|c|}{ Panel A: Election Data (1949-2010) } \\
\hline \multicolumn{6}{|l|}{ Parliamentary Elections } \\
\hline Turnout (\%) & 171 & 0.90 & 0.07 & 0.70 & 0.98 \\
\hline Invalid Votes(\%) & 171 & 0.02 & 0.01 & 0.01 & 0.05 \\
\hline Votes Right (\%) & 171 & 0.52 & 0.09 & 0.22 & 0.75 \\
\hline Votes Left (\%) & 171 & 0.40 & 0.10 & 0.15 & 0.62 \\
\hline Number of Parties & 171 & 6.96 & 2.94 & 4.00 & 13.00 \\
\hline Vote Share Winner (\%) & 171 & 0.47 & 0.08 & 0.29 & 0.65 \\
\hline Margin of Victory (\%) & 171 & 0.12 & 0.09 & 0.00 & 0.40 \\
\hline \multicolumn{6}{|l|}{ State Elections } \\
\hline Turnout (\%) & 121 & 0.86 & 0.09 & 0.61 & 0.98 \\
\hline Invalid Votes(\%) & 121 & 0.02 & 0.01 & 0.01 & 0.08 \\
\hline Votes Right (\%) & 121 & 0.53 & 0.11 & 0.21 & 0.76 \\
\hline Votes Left $(\%)$ & 121 & 0.39 & 0.11 & 0.10 & 0.62 \\
\hline Number of Parties & 121 & 5.98 & 1.05 & 4.00 & 8.00 \\
\hline Vote Share Winner (\%) & 121 & 0.49 & 0.06 & 0.36 & 0.65 \\
\hline Margin of Victory $(\%)$ & 121 & 0.10 & 0.07 & 0.00 & 0.34 \\
\hline \multicolumn{6}{|l|}{ Presidential Elections } \\
\hline Turnout (\%) & 132 & 0.88 & 0.13 & 0.38 & 1.00 \\
\hline Invalid Votes(\%) & 135 & 0.04 & 0.02 & 0.01 & 0.11 \\
\hline \multicolumn{6}{|c|}{ Panel B: Yearly State Data (1980-2012) } \\
\hline Unemployment Rate (\%) & 297 & 0.06 & 0.02 & 0.00 & 0.10 \\
\hline Population (in thousands) & 297 & 890 & 492 & 269 & 1717 \\
\hline Administrative Expenditures & 297 & 898.67 & 779.60 & 118.98 & 4303.17 \\
\hline Representatives and gen. admin & 297 & 423.67 & 431.13 & 74.81 & 2280.97 \\
\hline Finance & 297 & 475.00 & 485.26 & 42.20 & 3699.91 \\
\hline Welfare Expenditures & 297 & 1977.86 & 1415.89 & 341.19 & 6916.49 \\
\hline Education, sports and science & 297 & 636.42 & 399.04 & 138.80 & 1774.97 \\
\hline Social welfare and housing & 297 & 701.01 & 521.13 & 106.37 & 2315.46 \\
\hline Health & 297 & 569.51 & 548.88 & 81.82 & 2977.10 \\
\hline Arts, culture and religion & 297 & 70.92 & 62.89 & 9.91 & 288.36 \\
\hline Infrastructure Expenditures & 297 & 763.11 & 1141.22 & 72.16 & 4818.05 \\
\hline Roads and transport & 297 & 230.64 & 211.70 & 47.55 & 1010.88 \\
\hline Public order and security & 297 & 26.03 & 39.55 & 1.21 & 163.66 \\
\hline Promotion of the economy & 297 & 121.33 & 64.87 & 21.13 & 318.33 \\
\hline Services & 297 & 385.11 & 933.29 & 0.98 & 4055.52 \\
\hline
\end{tabular}

Notes: State-level election data covers all elections held from 1949 to 2010. Turnout measures the percentage of registered voters who issued a vote, and invalid votes is the proportion of ballots considered invalid. Vote shares for the right and left are the percentage of valid votes that went to ÖVP + FPÖ and SPÖ + KPÖ, respectively. The vote share of the winner is the percentage of valid votes obtained by the highest ranking party in each state, and margin of victory is the difference in vote shares between the highest ranking party and the runner-up. Expenditure, unemployment, and population data at the state-level cover all the years from 1980 to 2012. All state expenditures are expressę in millions of 2010 euros. 
Table 2: Descriptive Statistics: 1986 and 2003 Austrian Social Survey

\begin{tabular}{|c|c|c|c|c|c|}
\hline & Observations & Mean & Std. Dev & Min & Max \\
\hline \multicolumn{6}{|l|}{ Turnout } \\
\hline Voted in Last Parliamentary Elections (\%) & 3693 & 0.88 & 0.33 & 0.00 & 1.00 \\
\hline \multicolumn{6}{|l|}{ Political Party of Preference } \\
\hline $\begin{array}{l}\text { Left }(\%) \\
\text { Right }(\%) \\
\text { Minor Parties }(\%) \\
\text { No Party Preference }(\%) \\
\text { Not member of a Political Party }(\%)\end{array}$ & $\begin{array}{l}3637 \\
3637 \\
3637 \\
3637 \\
3661\end{array}$ & $\begin{array}{l}0.33 \\
0.31 \\
0.07 \\
0.30 \\
0.82\end{array}$ & $\begin{array}{l}0.47 \\
0.46 \\
0.25 \\
0.46 \\
0.39\end{array}$ & $\begin{array}{l}0.00 \\
0.00 \\
0.00 \\
0.00 \\
0.00\end{array}$ & $\begin{array}{l}1.00 \\
1.00 \\
1.00 \\
1.00 \\
1.00\end{array}$ \\
\hline \multicolumn{6}{|l|}{ Interest in Politics and Information } \\
\hline $\begin{array}{l}\text { Uninterested in Politics (\%) } \\
\text { Mildly Interested in Politics(\%) } \\
\text { Very Interested in Politics (\%) } \\
\text { Doesn't read newspaper regularly }\end{array}$ & $\begin{array}{l}3693 \\
3693 \\
3693 \\
3672\end{array}$ & $\begin{array}{l}0.36 \\
0.40 \\
0.24 \\
0.31\end{array}$ & $\begin{array}{l}0.48 \\
0.49 \\
0.43 \\
0.46\end{array}$ & $\begin{array}{l}0.00 \\
0.00 \\
0.00 \\
0.00\end{array}$ & $\begin{array}{l}1.00 \\
1.00 \\
1.00 \\
1.00\end{array}$ \\
\hline \multicolumn{6}{|l|}{ Socioeconomic Variables } \\
\hline $\begin{array}{l}\text { Age } \\
\text { Female } \\
\text { Household Income (in } 2003 \text { Euros) } \\
\text { Number of Members in Household } \\
\text { Employed (\%) } \\
\text { Unemployed (\%) } \\
\text { Retired (\%) }\end{array}$ & $\begin{array}{l}3693 \\
3693 \\
2886 \\
3693 \\
3693 \\
3693 \\
3693\end{array}$ & $\begin{array}{c}48.14 \\
0.58 \\
1796.38 \\
2.84 \\
0.49 \\
0.03 \\
0.27\end{array}$ & $\begin{array}{c}16.69 \\
0.49 \\
964.75 \\
1.57 \\
0.50 \\
0.17 \\
0.44\end{array}$ & $\begin{array}{c}19.00 \\
0.00 \\
180.00 \\
1.00 \\
0.00 \\
0.00 \\
0.00\end{array}$ & $\begin{array}{c}93.00 \\
1.00 \\
4341.90 \\
9.00 \\
1.00 \\
1.00 \\
1.00\end{array}$ \\
\hline \multicolumn{6}{|l|}{ Educational Attainment } \\
\hline $\begin{array}{l}\text { Compulsory Schooling }(\%) \\
\text { Vocational Middle School }(\%) \\
\text { High School }(\%) \\
\text { College }(\%)\end{array}$ & $\begin{array}{l}3693 \\
3693 \\
3693 \\
3693\end{array}$ & $\begin{array}{l}0.65 \\
0.13 \\
0.16 \\
0.06\end{array}$ & $\begin{array}{l}0.48 \\
0.34 \\
0.37 \\
0.24\end{array}$ & $\begin{array}{l}0.00 \\
0.00 \\
0.00 \\
0.00\end{array}$ & $\begin{array}{l}1.00 \\
1.00 \\
1.00 \\
1.00\end{array}$ \\
\hline
\end{tabular}

Notes: The sample includes all individuals in the 1986 and 2003 Austrian Social Survey who reported whether they voted in the last parliamentary elections (1983 and 2002) and were eligible to vote. Political party of preference specifies the party the respondent identifies with (left if SPÖ or KPÖ, right if ÖVP or FPÖ, no party preference if the individual doesn't identify with any party, and minor parties otherwise), and not a member of a political party is a dummy for whether the individual has no party affiliation. Individuals are separated into three categories according to whether they manifest to be uninterested, mildly or very interested in politics. The Austrian Social Survey separates household income into 21 different categories. To make the figures comparable across periods, we imputed household income as the midpoint of the category into which individuals fell, and converted the 1986 mid-point into 2003 euros. Educational variables are mutually exclusive dummies for the maximum educational attainment. 


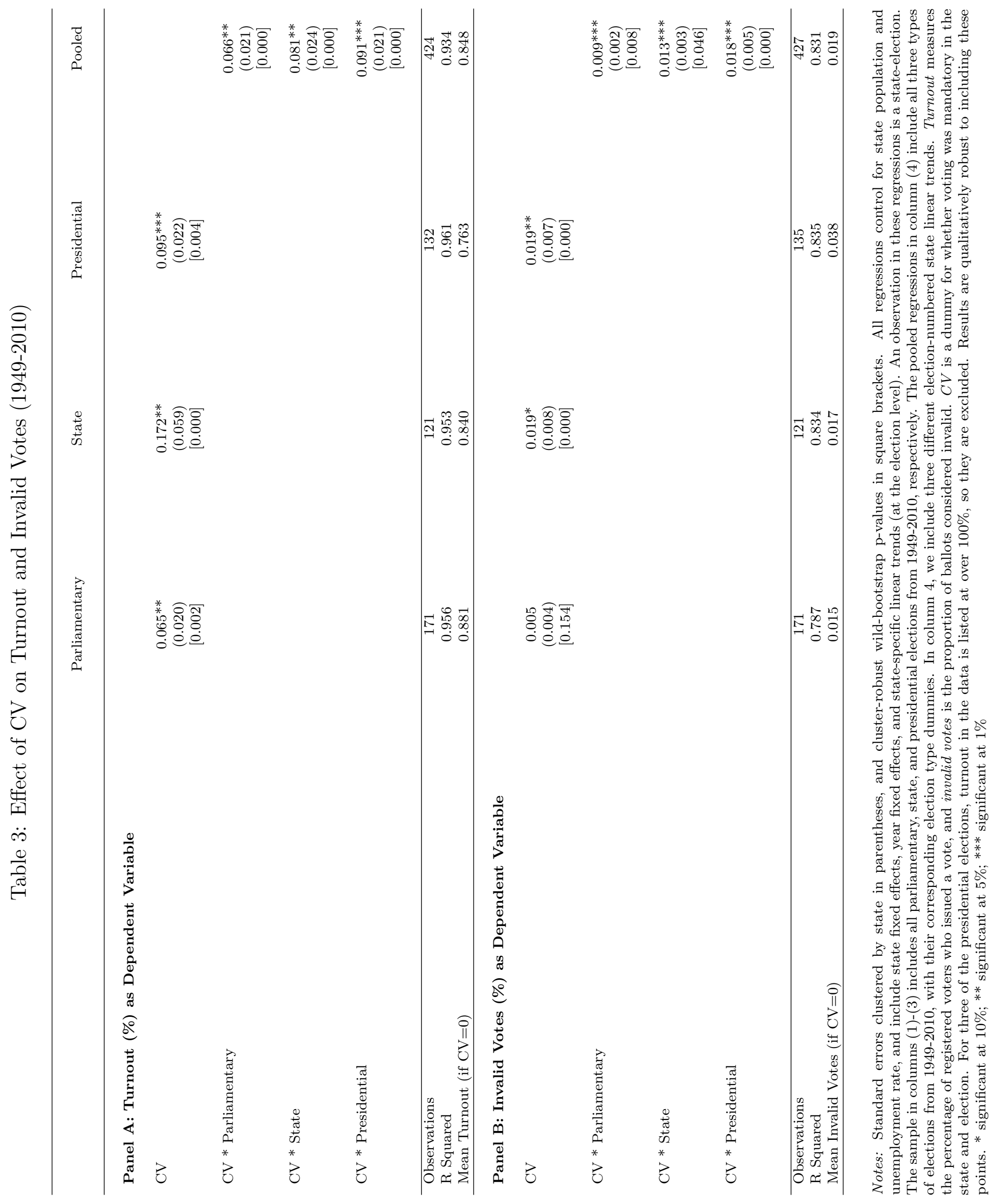




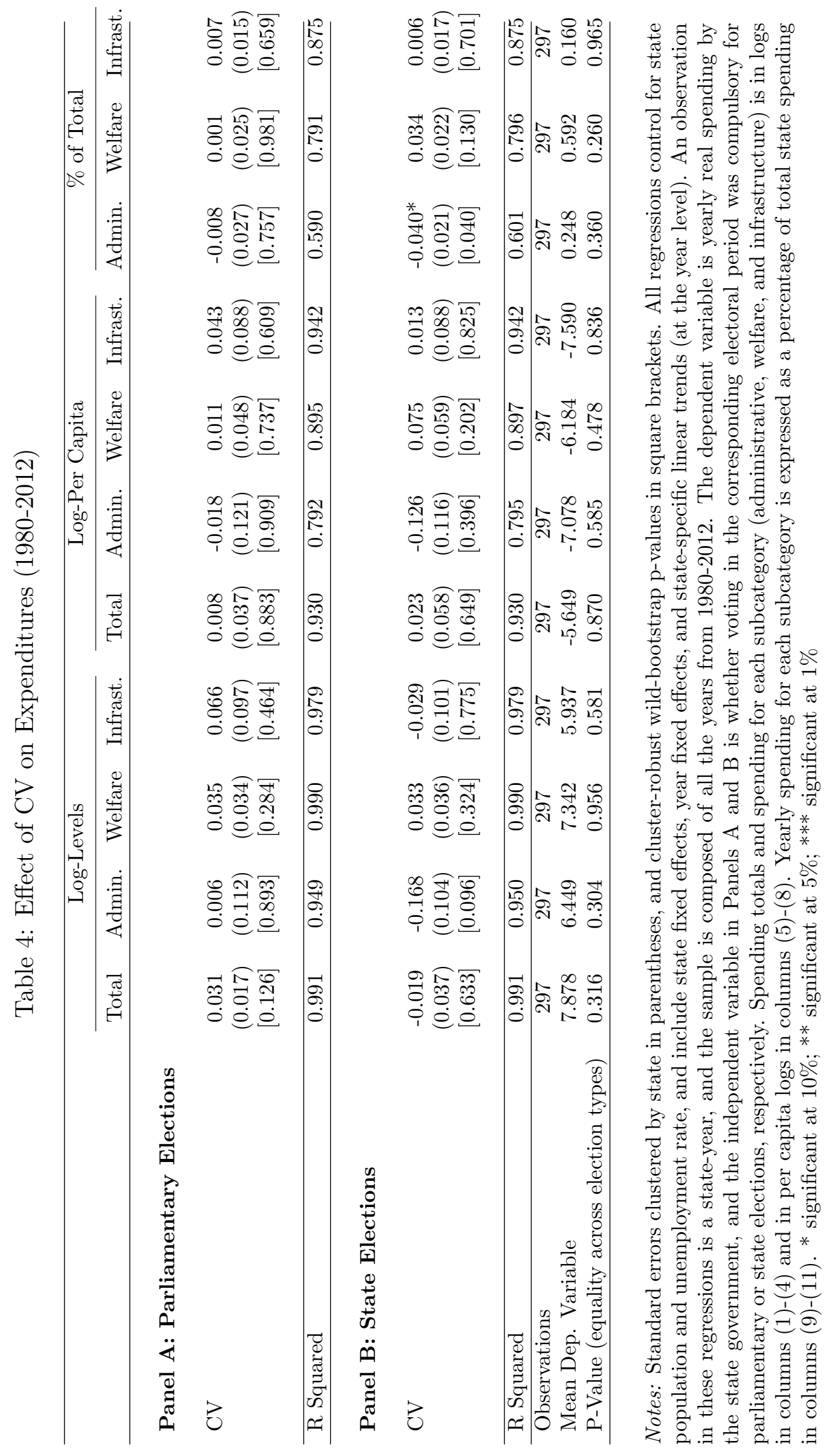




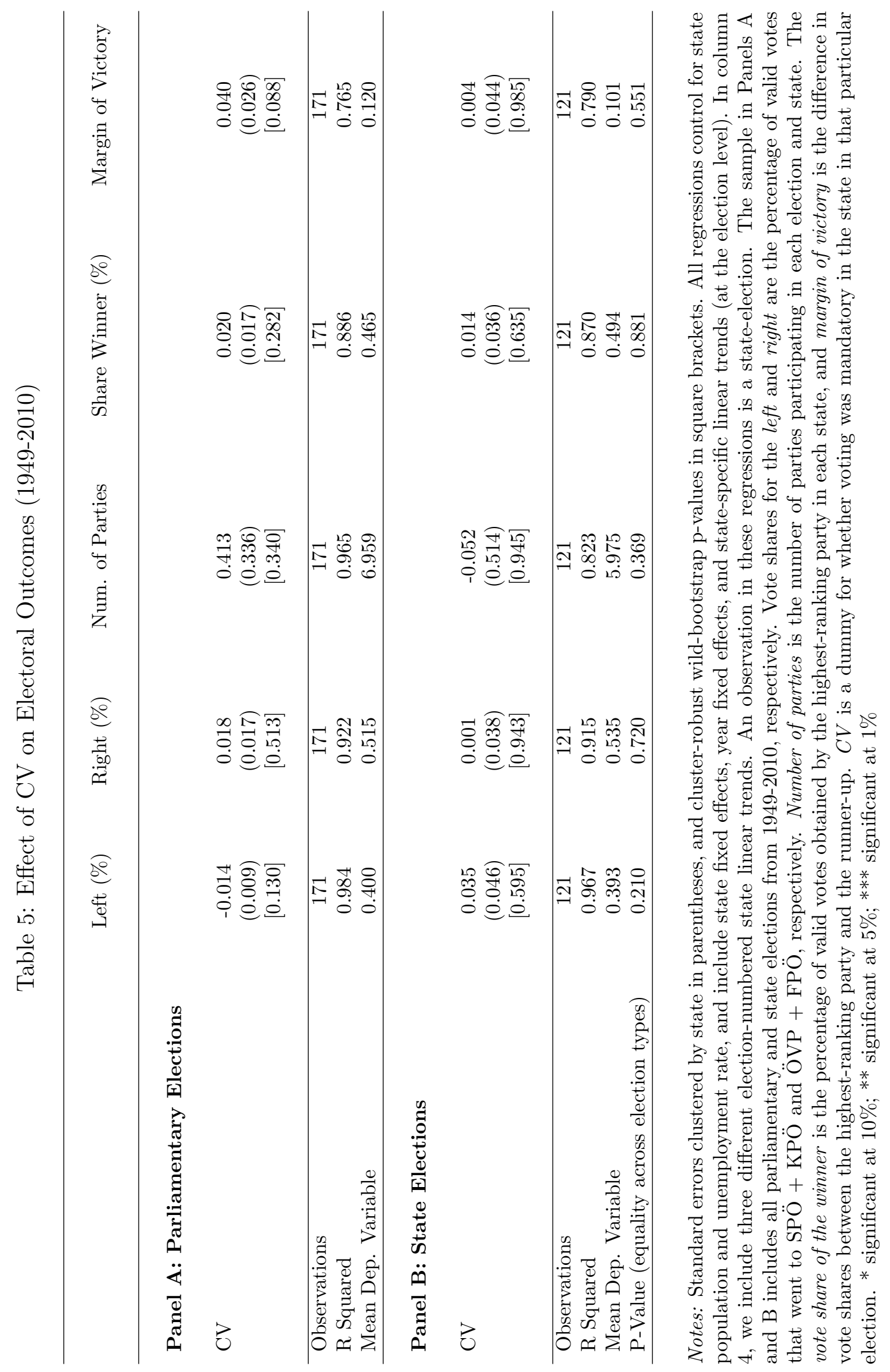




\section{Table 6: Individual-level Impact of CV on Turnout: Heterogeneity by Voter Characteristics}

Dependent Variable: Voted in Last Parliamentary Elections

\begin{tabular}{|c|c|c|c|}
\hline \multicolumn{2}{|l|}{ 1) Effect of CV on Turnout } & \multicolumn{2}{|l|}{ 5) Party Membership } \\
\hline $\mathrm{CV}$ & $\begin{array}{c}0.042 \\
(0.028) \\
{[0.193]}\end{array}$ & Not Party Member * CV & $\begin{array}{c}0.054^{*} \\
(0.028) \\
{[0.229]}\end{array}$ \\
\hline & & Party Member * CV & $\begin{array}{c}-0.006 \\
(0.026) \\
{[0.912]}\end{array}$ \\
\hline 2) Gender & & 6) Informed. vs Uninformed Citizens & \\
\hline Female $* \mathrm{CV}$ & $\begin{array}{c}0.059^{*} \\
(0.031) \\
{[0.207]}\end{array}$ & Uninformed $* \mathrm{CV}$ & $\begin{array}{c}0.072^{* *} \\
(0.026) \\
{[0.189]}\end{array}$ \\
\hline Male $* \mathrm{CV}$ & $\begin{array}{c}0.019 \\
(0.025) \\
{[0.554]}\end{array}$ & Informed $* \mathrm{CV}$ & $\begin{array}{c}0.031 \\
(0.029) \\
{[0.363]}\end{array}$ \\
\hline 3) Educational Attainment & & 7) Interest in Politics & \\
\hline Compulsory Schooling $*$ CV & $\begin{array}{c}0.038 \\
(0.027) \\
{[0.177]}\end{array}$ & Uninterested $* \mathrm{CV}$ & $\begin{array}{c}0.078^{*} \\
(0.039) \\
{[0.203]}\end{array}$ \\
\hline Vocational Middle School * CV & $\begin{array}{c}0.078^{*} \\
(0.041) \\
{[0.283]}\end{array}$ & Mildly Interested $* \mathrm{CV}$ & $\begin{array}{c}0.029 \\
(0.025) \\
{[0.279]}\end{array}$ \\
\hline High School or College $*$ CV & $\begin{array}{c}0.027 \\
(0.045) \\
{[0.572]}\end{array}$ & Very Interested $* \mathrm{CV}$ & $\begin{array}{l}-0.006 \\
(0.027) \\
{[0.792]}\end{array}$ \\
\hline 4) Income Quartile & & 8) Self-Reported Political Preference & \\
\hline Income Q1 * CV & $\begin{array}{c}0.061 \\
(0.033) \\
{[0.227]}\end{array}$ & Left $* \mathrm{CV}$ & $\begin{array}{c}0.028 \\
(0.035) \\
{[0.411]}\end{array}$ \\
\hline Income Q2 * CV & $\begin{array}{c}0.052 \\
(0.036) \\
{[0.289]}\end{array}$ & Right $* \mathrm{CV}$ & $\begin{array}{c}0.021 \\
(0.018) \\
{[0.289]}\end{array}$ \\
\hline Income Q3 $* \mathrm{CV}$ & $\begin{array}{c}0.022 \\
(0.030) \\
{[0.499]}\end{array}$ & Minor Parties * CV & $\begin{array}{c}-0.050 \\
(0.149) \\
{[0.908]}\end{array}$ \\
\hline Income Q4 $* \mathrm{CV}$ & $\begin{array}{c}0.024 \\
(0.040) \\
{[0.548]}\end{array}$ & No Party Preference ${ }^{*} \mathrm{CV}$ & $\begin{array}{c}0.138^{*} \\
(0.069) \\
{[0.103]}\end{array}$ \\
\hline
\end{tabular}

Notes: This table presents 8 separate regressions numbered 1-8. Except for regression 1, the coefficients shown are interactions of $C V$ with individual characteristics. In regression 6, we use whether someone regularly reads the newspaper as a proxy for whether they are informed. Standard errors clustered by state in parentheses, and cluster-robust wild-bootstrap p-values in square brackets. The dependent variable in all regressions is a dummy for whether the individual voted in the previous parliamentary elections. $C V$ is a dummy for whether voting was compulsory for that election in the individual's state of residence. All regressions include baseline controls for age, age squared, gender, educational attainment, parents' education, working status, household size, community size, self-reported political preference, party membership, being informed, interest in politics, state fixed effects, and survey year fixed effects. Regression 4 includes income quartile controls (excluded from the other regressions because they sometimes have missing data). The sample includes all individuals in the 1986 and 2003 Austrian Social Survey who reported whether they voted in the last parliamentary elections (1983 and 2002 ) and were eligible to vote. Regression 4 has 2,620 observations, whereas all other regressions have 3,339 observations. * significant at $10 \% ; * *$ significant at $5 \% ; * *$ significant at $1 \%$ 


\section{FOR ONLINE PUBLICATION ONLY}

Appendix A Appendix Tables 


\section{Administrative Expenses}

i) Elected representatives and general administration:

State parliament, state government, state government delegations, sub-state governments, special offices, committees, pensions, personnel expenses, and other tasks of the public administration.

\section{ii) Finance:}

Capital assets and unincorporated foundations, financial allocations and grants, liabilities, budgetary compensation, and handover and takeover of the annual results.

\section{Welfare Expenses}

i) Education, sports and science:

Secondary education, vocational education and teacher formation, preschool education, education promotion, extracurricular educational activities for the youth, sports and extracurricular physical education, adult educa-

tion, and research and science.

\section{ii) Social welfare and promotion of house construction:}

General public welfare, youth welfare, emergency funds, social and family policies, and housing subsidies.

\section{iii) Health:}

Health services, environmental protection, rescue and warning services, health worker training, public hospitals, hospitals operated by other legal entities, and veterinary medicine.

iv) Arts, culture and religion:

Fine arts, music and performing arts, literature and language, museums, heritage preservation, radio, press, films, and church affairs.

\section{Infrastructure Expenses}

i) Road construction, hydraulic engineering and transport:

Road construction and maintenance, hydraulic construction, flood protection, road/rail/water traffic, aviation, and postal and telecommunication services.

\section{ii) Promotion of the economy:}

Improvement and promotion of agriculture and forestry, promotion of energy, tourism, trade, commerce, and industry.

\section{iii) Services:}

Public services (water supply, lighting, waste management, etc.), residential and commercial buildings, and utility companies.

\section{iv) Public order and security:}

Public order, security and special police, firefighting, disaster relief and national defense.

Notes: Detailed breakdown of each category was obtained from Appendix 2 of the 787/1996 Ministry of Finance regulation on budgeting and accounts (Voranschlags- und Rechnungsabschluverordnung VRV). 


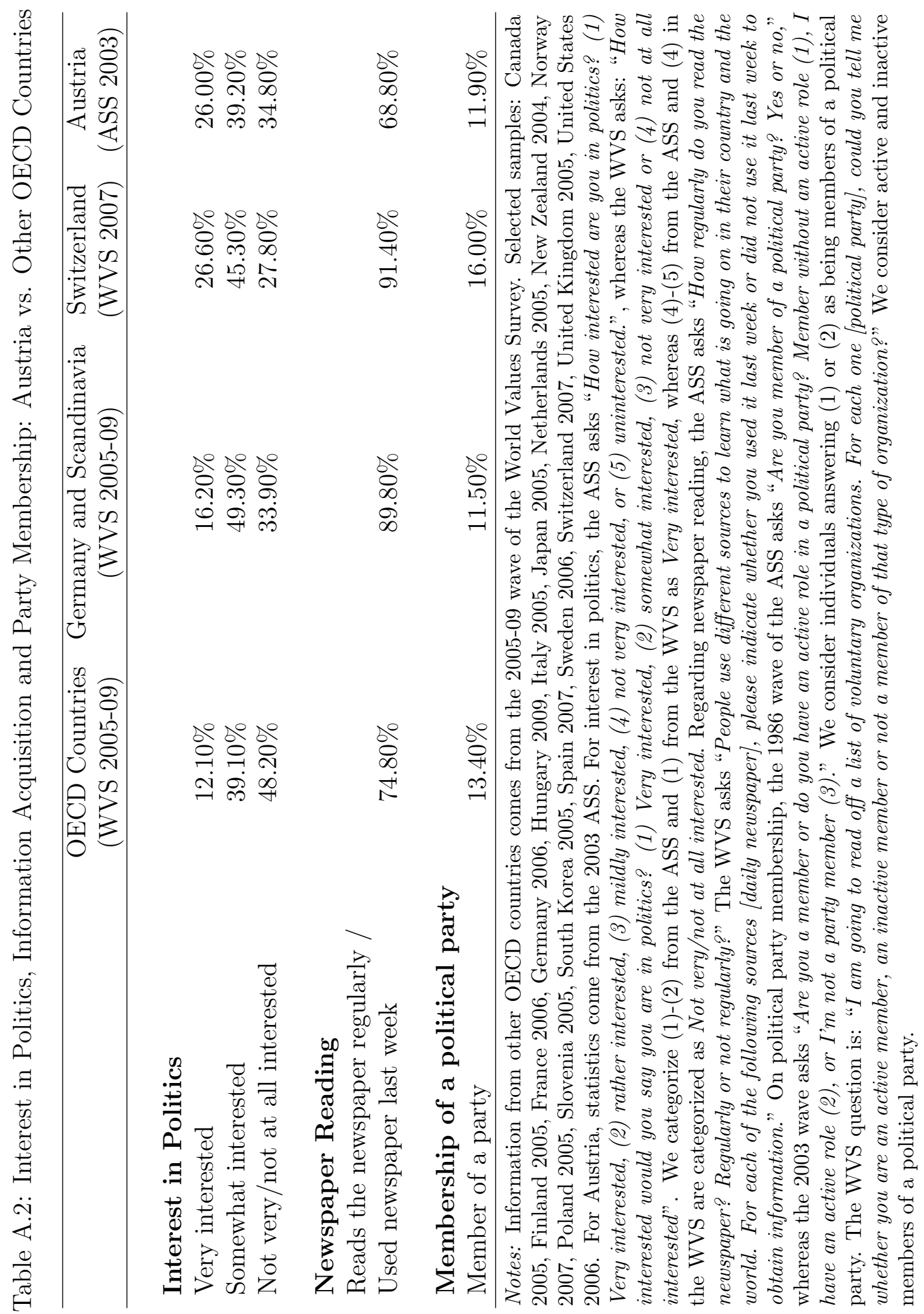




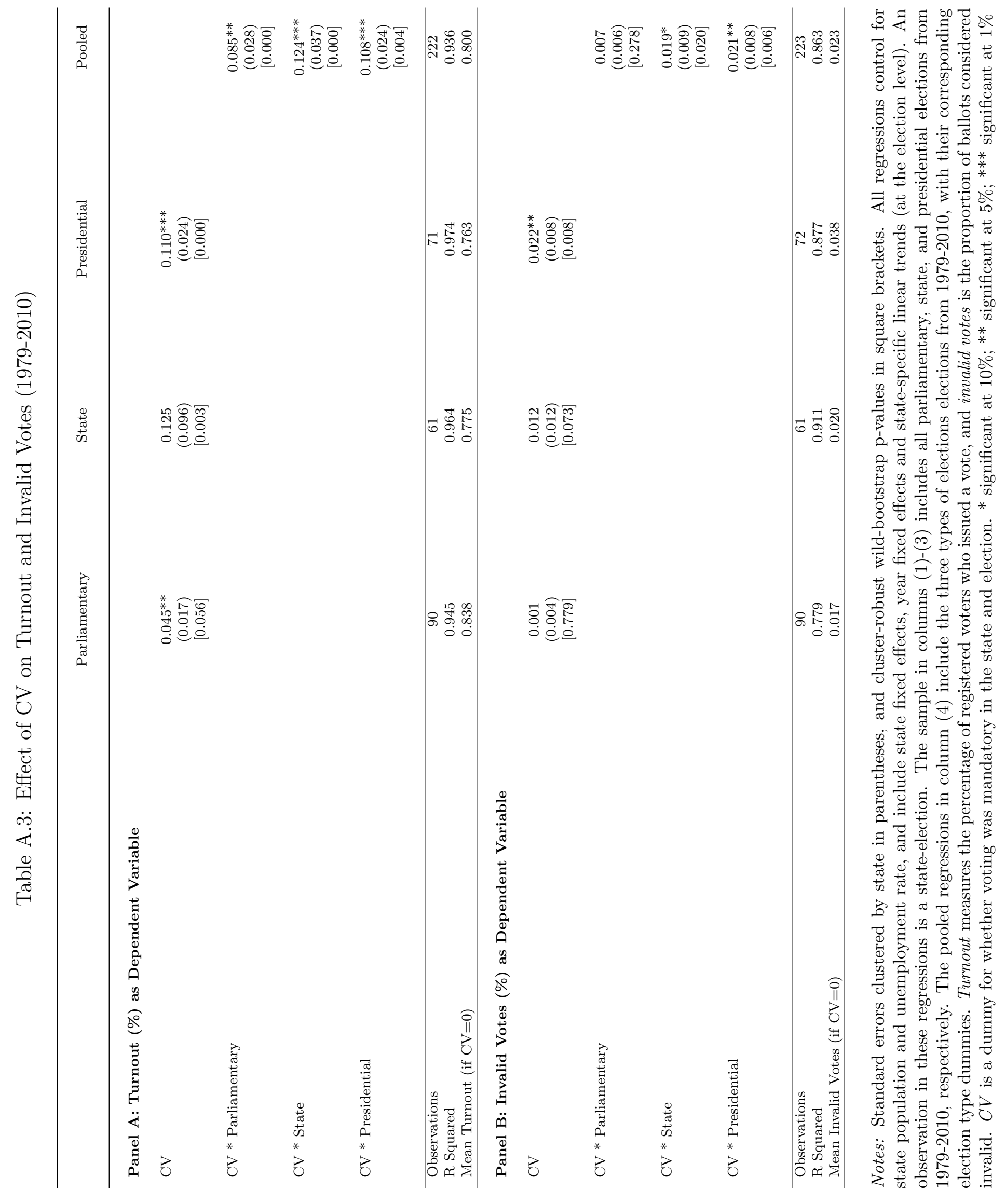




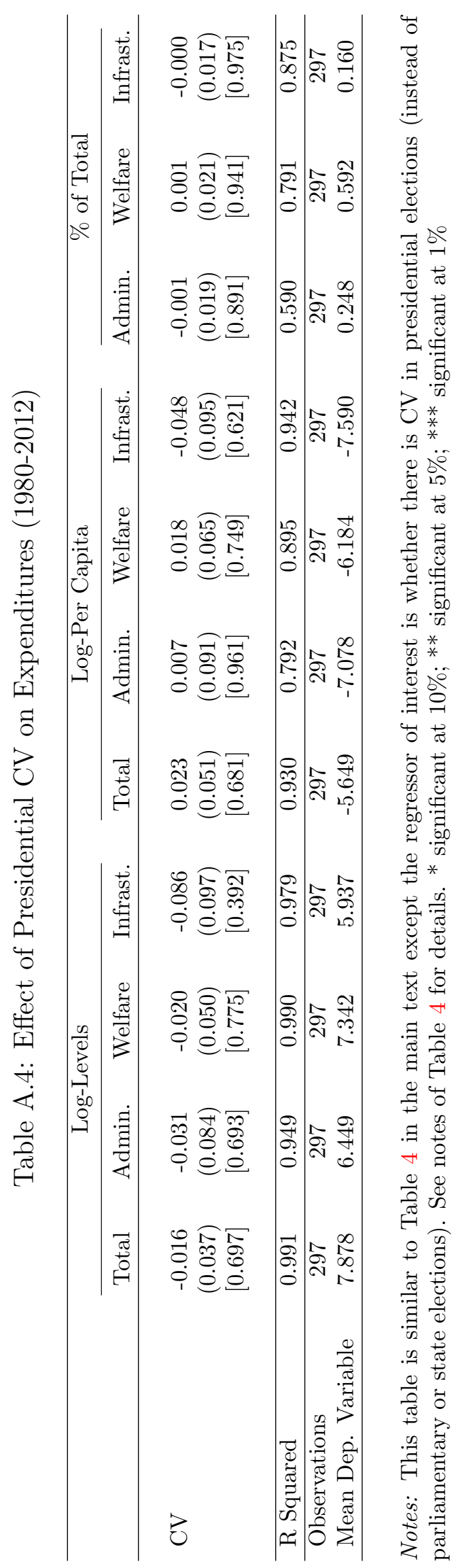




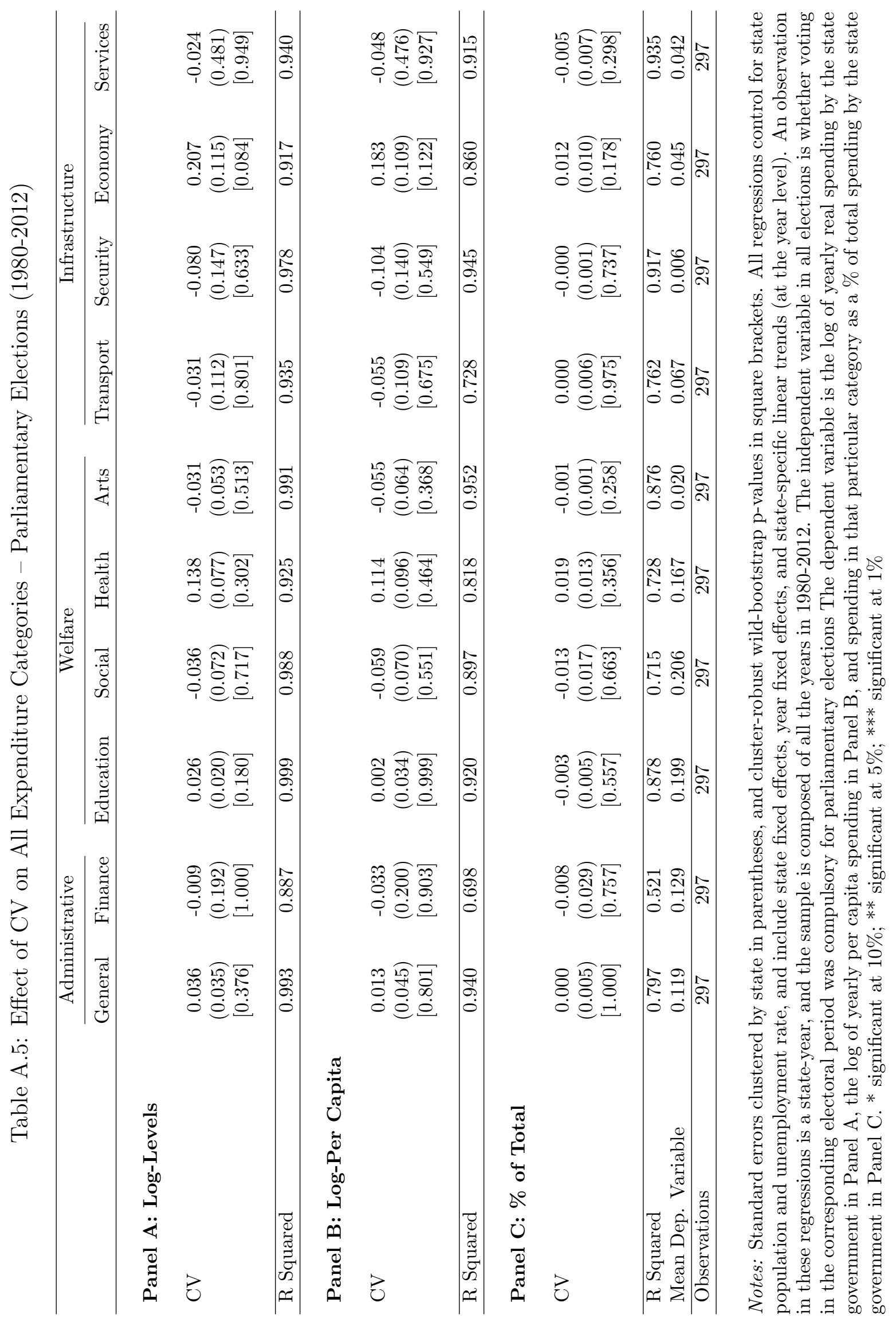




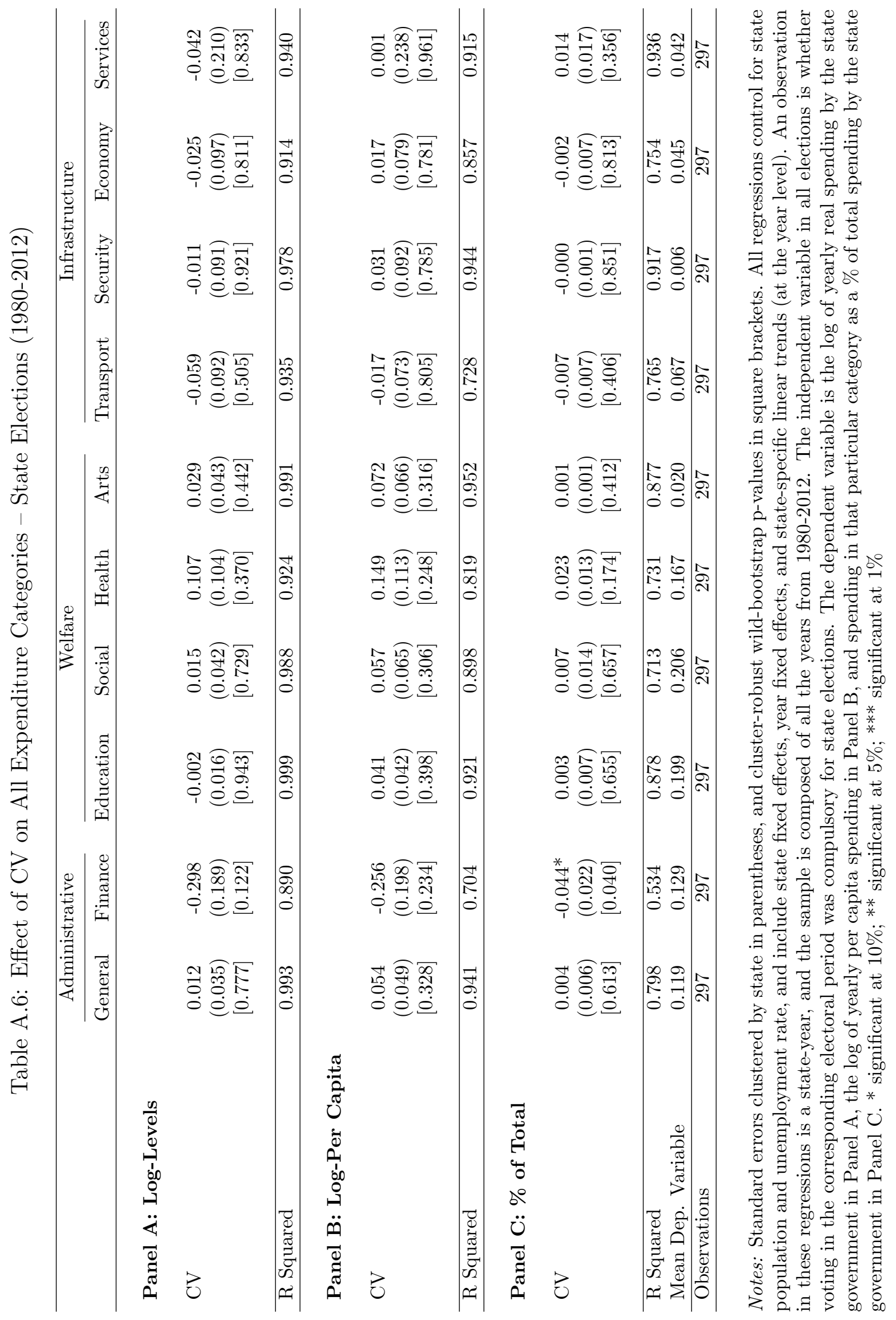




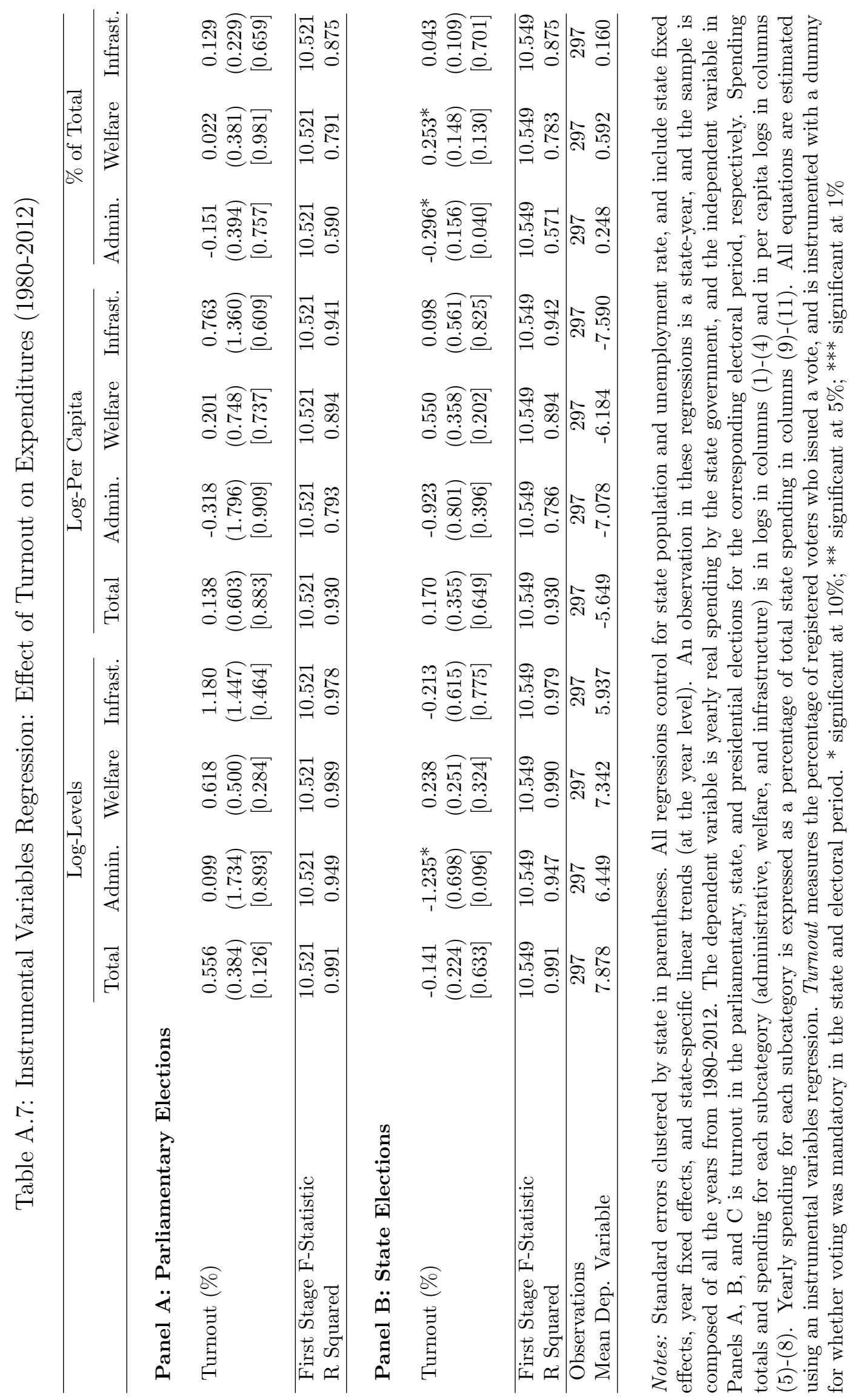




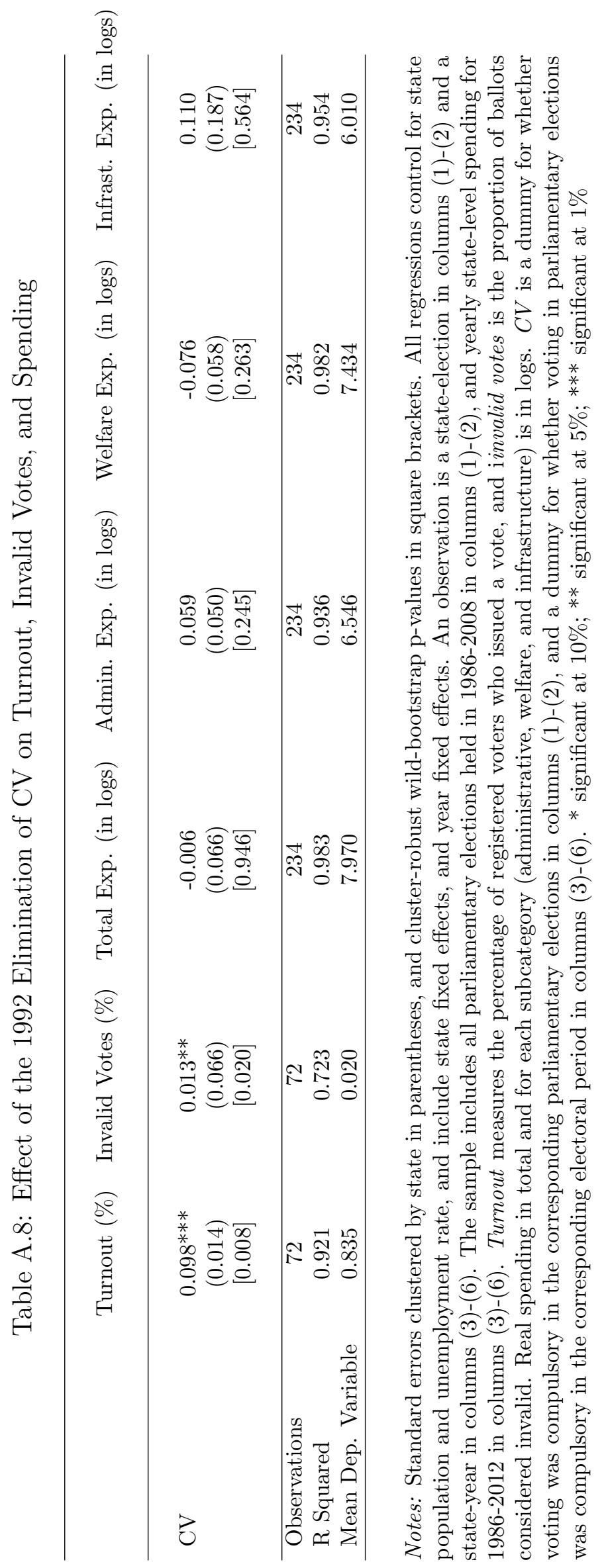


Table A.9: Robustness Check: Effect of CV on Turnout and Invalid Votes

\begin{tabular}{|c|c|c|}
\hline & Turnout (\%) & Invalid Votes (\%) \\
\hline $\mathrm{CV}(\mathrm{t}+1) *$ Parliamentary & $\begin{array}{l}-0.017 \\
(0.020) \\
{[0.348]}\end{array}$ & $\begin{array}{l}-0.000 \\
(0.005) \\
{[0.919]}\end{array}$ \\
\hline $\mathrm{CV}(\mathrm{t}) *$ Parliamentary & $\begin{array}{c}0.098^{* *} \\
(0.037) \\
{[0.018]}\end{array}$ & $\begin{array}{c}0.009 \\
(0.007) \\
{[0.246]}\end{array}$ \\
\hline $\mathrm{CV}(\mathrm{t}-1) *$ Parliamentary & $\begin{array}{l}-0.011 \\
(0.020) \\
{[0.573]}\end{array}$ & $\begin{array}{c}0.003 \\
(0.003) \\
{[0.168]}\end{array}$ \\
\hline $\mathrm{CV}(\mathrm{t}+1) *$ State & $\begin{array}{l}-0.003 \\
(0.014) \\
{[0.869]}\end{array}$ & $\begin{array}{c}0.001 \\
(0.008) \\
{[0.895]}\end{array}$ \\
\hline $\mathrm{CV}(\mathrm{t}) *$ State & $\begin{array}{l}0.109^{*} \\
(0.049) \\
{[0.000]}\end{array}$ & $\begin{array}{l}0.018^{*} \\
(0.008) \\
{[0.056]}\end{array}$ \\
\hline CV $(\mathrm{t}-1) *$ State & $\begin{array}{l}-0.017 \\
(0.055) \\
{[0.761]}\end{array}$ & $\begin{array}{l}-0.007 \\
(0.004) \\
{[0.270]}\end{array}$ \\
\hline $\mathrm{CV}(\mathrm{t}+1) *$ Presidential & $\begin{array}{l}-0.026^{*} \\
(0.012) \\
{[0.034]}\end{array}$ & $\begin{array}{l}-0.003 \\
(0.006) \\
{[0.613]}\end{array}$ \\
\hline $\mathrm{CV}(\mathrm{t}) *$ Presidential & $\begin{array}{c}0.078^{* * *} \\
(0.017) \\
{[0.006]}\end{array}$ & $\begin{array}{l}0.012^{*} \\
(0.006) \\
{[0.032]}\end{array}$ \\
\hline $\mathrm{CV}(\mathrm{t}-1) *$ Presidential & $\begin{array}{l}-0.028 \\
(0.017) \\
{[0.358]}\end{array}$ & $\begin{array}{l}-0.001 \\
(0.004) \\
{[0.741]}\end{array}$ \\
\hline $\begin{array}{l}\text { Observations } \\
\text { R Squared } \\
\text { Mean Dep. Variable (if } \mathrm{CV}=0)\end{array}$ & $\begin{array}{c}388 \\
0.935 \\
0.848\end{array}$ & $\begin{array}{c}391 \\
0.853 \\
0.019\end{array}$ \\
\hline
\end{tabular}

Notes: Standard errors clustered by state in parentheses, and cluster-robust wild-bootstrap p-values in square brackets. All regressions control for state population and unemployment rate, and include state fixed effects, year fixed effects, state-specific linear trends (at the election level), and election type dummies. An observation in these regressions is a state-election, and the sample includes all parliamentary, state, and presidential elections from 1949-2010. Turnout measures the percentage of registered voters who issued a vote, and invalid votes is the proportion of ballots considered invalid. $C V$ dummies and their lags and leads indicate whether voting was mandatory in a state and election. ${ }^{*}$ significant at $10 \% ;{ }^{* *}$ significant at $5 \%$; ${ }^{* *}$ significant at $1 \%$ 


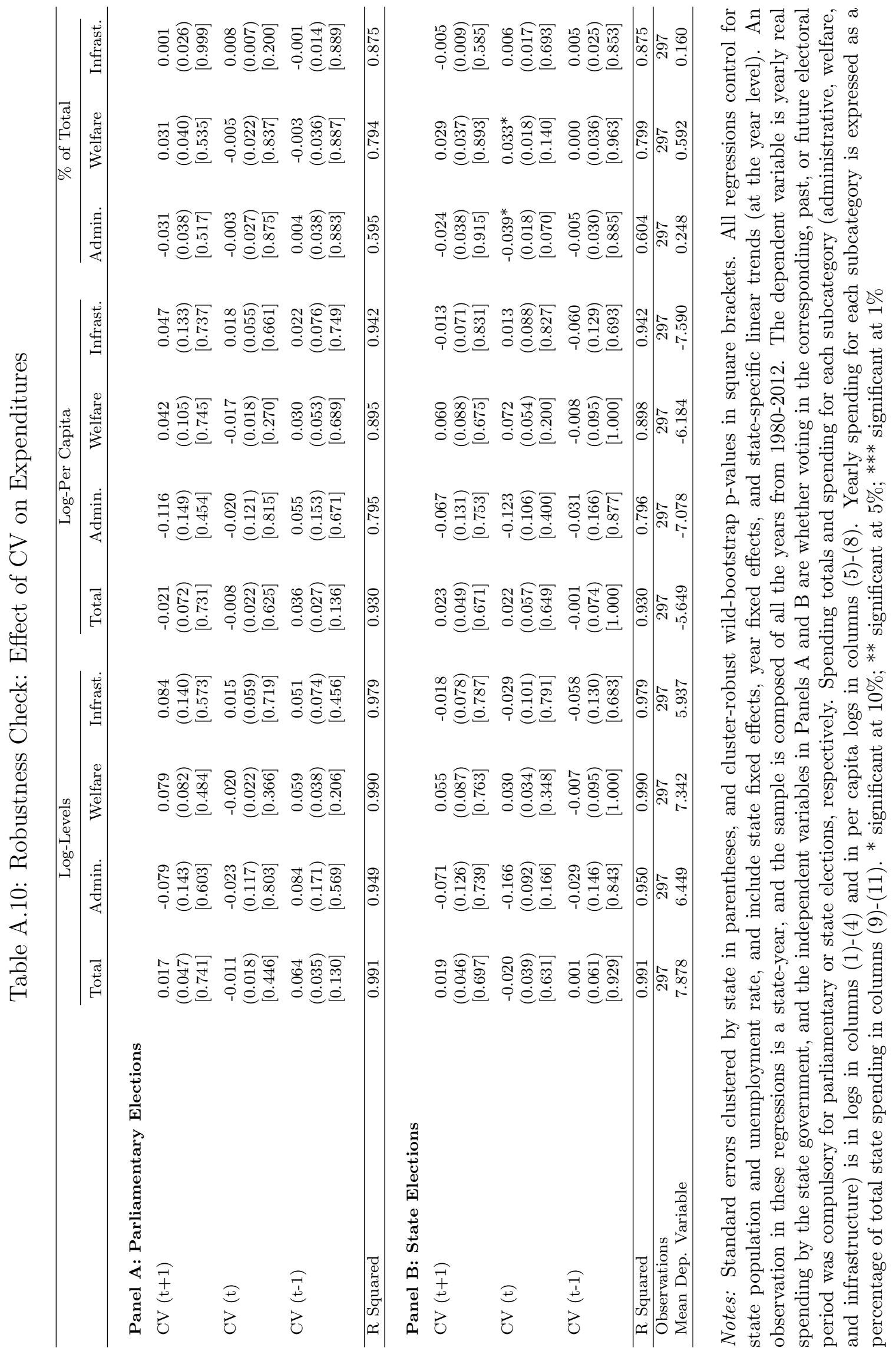




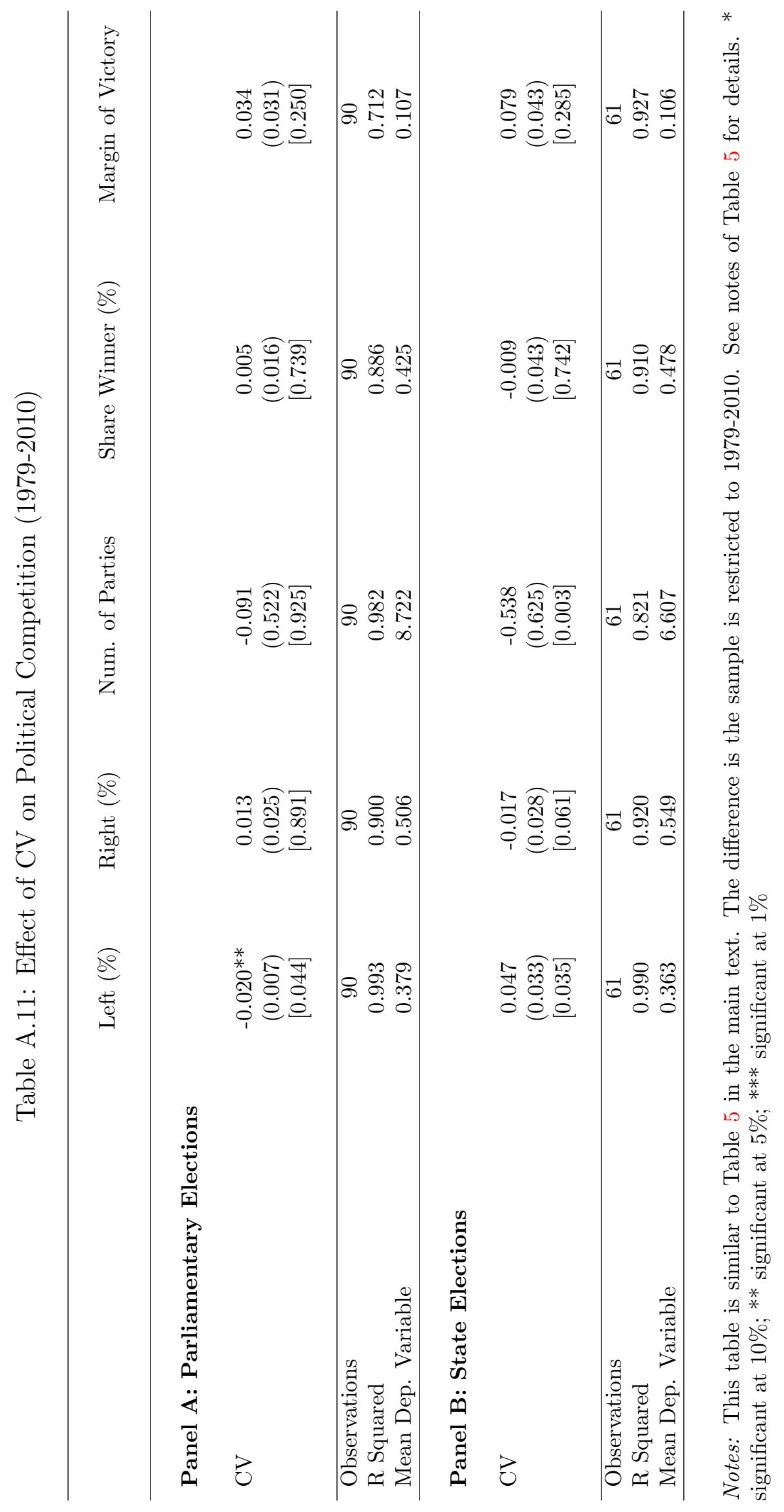




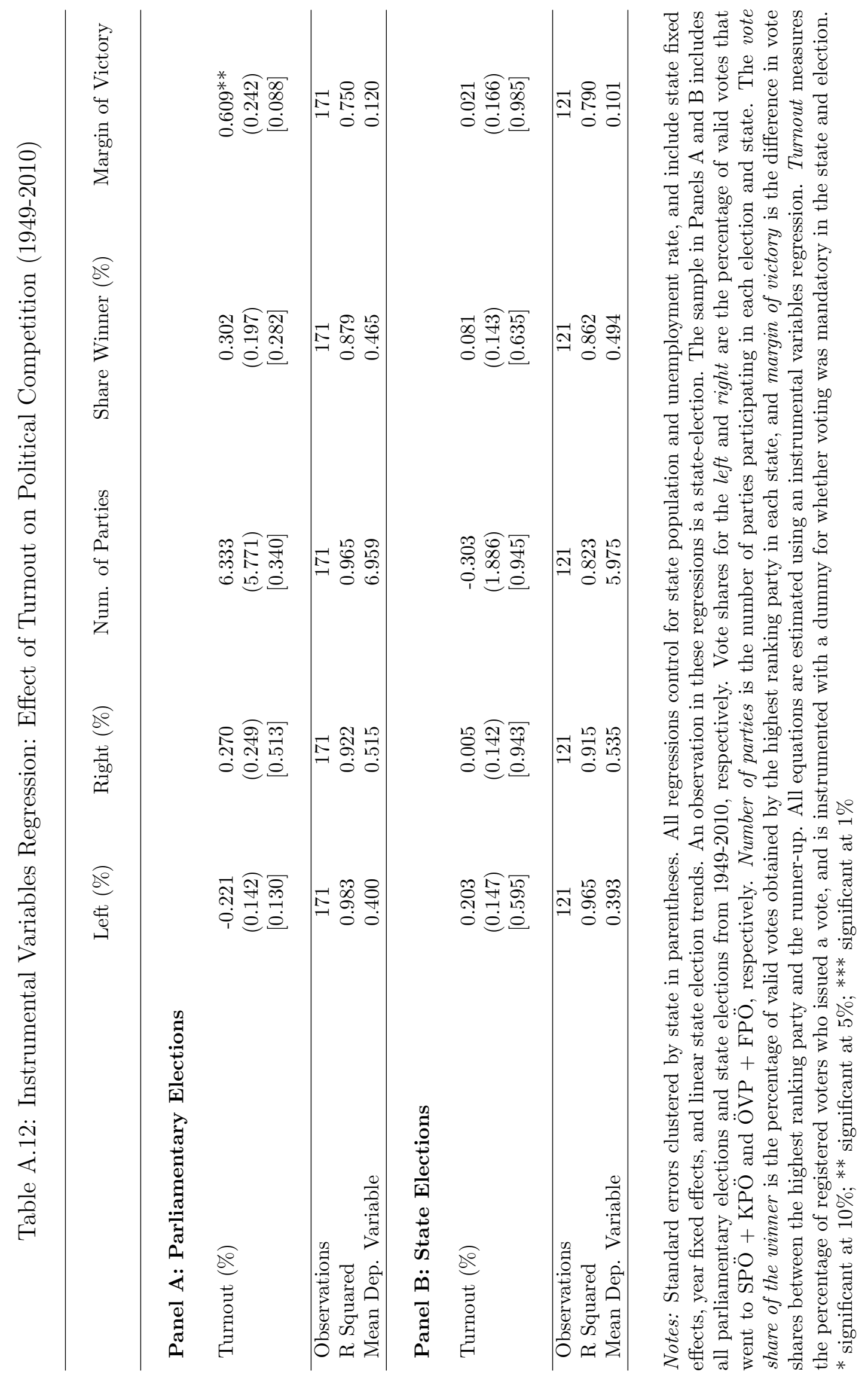




\section{Appendix B Institutional Background}

\section{Appendix B.1 Compulsory Voting in Austria in the pre-war Period}

The debate concerning the introduction of CV in Austria goes back to the enfranchisement of women in 1918. Conservative parties feared that their women supporters would not be as politically active and easy to mobilize as women who supported the Social Democrats, who had advocated for universal voting rights. CV was therefore seen as an instrument for conserving their power. Informal accounts mention that during the debates regarding the implementation of $\mathrm{CV}$, conservatives put forward the argument that participation in political decisions and public life was not only a right but a duty of every citizen. ${ }^{45}$ Social Democrats were against its implementation, and thus a compromise was reached, leaving the prerogative of instating mandatory voting to the states. In 1919, before the elections for the Constituent National Assembly, provisions for CV were made in Vorarlberg and Tyrol. ${ }^{46}$ When the 1920 constitution was amended in December 1929, it became up to each state to decide whether voting was compulsory or not in national parliament and state parliament elections. ${ }^{47}$

The 1920 constitution, which was parliamentary in nature, underwent other important changes in 1929. The responsibilities of the president were broadened, and the election of the president became determined by popular vote rather than by decision of the members of the legislature. Furthermore, voting in presidential elections became mandatory in the whole country. ${ }^{48}$ Although the first election was supposed to occur in 1931, due to the worldwide economic depression, political parties decided to suspend the elections and reelect the incumbent president. In May 1934, the Fascist ruling party repealed the 1929 constitution, but after World War II, in May 1945, the 1920 constitution (with its 1929 amendments) was reinstated. Thus, both the country-wide provisions for mandatory voting in presidential elections and the state-determined CV in national parliament and state parliament elections were restored. In spite of this, and probably due to the post-war chaos, the 1945 national and state parliament elections were carried out according to a national law made specifically for this election. ${ }^{49}$ Thus, voting in the 1945 elections was optional for individuals in all states, including Tyrol and Vorarlberg. Only in the next election for national and state parliament, both held in 1949, did Vorarlberg and Tyrol re-implement CV. Furthermore, the state of Styria also enacted its own CV law for these elections. ${ }^{50}$

\footnotetext{
45 http://www. onb.ac.at/ariadne/projekte/frauenwaehlet/Raum07.html, last accessed March 16, 2016

${ }^{46}$ http://www . parlament.gv . at/PERK/HIS/WAHL/REGEL/index. shtml, last accessed March 16, 2016.

${ }^{47}$ Federal Constitution of December 1929 (B-VG) Articles 26 (1) and 95 (1)-(2).

${ }^{48}$ Federal Constitution of December 1929 (B-VG) Article 60 (1).

${ }^{49}$ Election Law 198 (Wahlgesetz) from October 1945.

${ }^{50}$ Styria Law 30 from July 11, 1949.
} 


\section{Appendix B.2 Fines for Abstention under Compulsory Voting}

Maximum fines for abstention in presidential and parliamentary elections with CV were established by the National Parliament, whereas state parliaments had the authority for establishing maximum fines for non-voting in state elections. In all three election types, however, the actual fine amounts and their enforcement were left to local governments. As described in Section 2.2, abstention penalties were extremely rare, since the law allowed for a wide range of excuses for not voting. ${ }^{51}$ Although there is no comprehensive information on the exact fines that individuals were charged with in the few cases in which these were enforced, anecdotal evidence suggests that fines were in fact much lower than the ceilings set by law.

Since each state had the authority for establishing maximum fines for non-voting in state elections, there was substantial variation across states (and time) in these maximum fines. When CV for state elections was established in Vorarlberg in 1919, fines varied depending on the socioeconomic status of the violator, ranging from 1 kronor(0.9 US dollars) to 50 Austrian kronor (44 USD). ${ }^{52}$ The law establishing the value of these fines was modified over time, and in 1988, for example, fines were capped at 10,000 schillings (1,413 USD). ${ }^{53}$ Although maximum penalties were high, this ceiling was not binding, and in practice fines were significantly lower. Only in very few cases were non-voters effectively fined, with fines around 300-500 schillings ( 42-71 USD). Non-voters from Vorarlberg were asked by the mayor of their municipality to provide reasons for abstention, but weren't required to provide any official proof. Those who didn't comply with this request within a week and were reported to the authorities were granted an extra two weeks to provide a justification for their abstention. In 1949, punishment for abstention in state elections in Styria was set at a maximum of 1,000 schillings and four weeks of imprisonment, following the maximum sanctions for abstention in federal elections. ${ }^{54}$ In the case of Tyrol, maximum fines for abstention in state parliament elections were always kept at 1,000 schillings, ranging due to inflation from around 506 USD in 1958 to 102 USD in 2002 when CV was eliminated (all in December 2015 values). ${ }^{55}$ While the aforementioned states formally sanctioned abstention in state parliament elections, the enactment of $\mathrm{CV}$ in Carinthia in 1986 only explicitly set a punishment for abstention in federal elections (matching the corresponding federal laws). For state parliament elections, the law only states that

\footnotetext{
${ }^{51}$ Private correspondence between the authors and government officials confirmed that fines were enforced in only a handful of cases. Additionally, the website http://www.idea.int/vt/compulsory_voting.cfm describes the sanctions for not voting as being "weakly enforced" (accessed March 16, 2016).

${ }^{52}$ Vorarlberg State Law enacted in January 27, 1919, Article 2.

${ }^{53}$ Vorarlberg State Law number 60 enacted in December 14, 1988, Article 73(3). All figures in schillings are expressed in nominal terms. To express these in current dollars, the schilling values are updated to their 2015 value using the Austrian CPI, and then converted to dollars using the appropriate exchange rate.

${ }^{54}$ Styria State Law enacted in July 11, 1949, Article 1(3).

${ }^{55}$ Tyrol State Law number 27, enacted in July 29, 1949; Tyrol State Law number 20, enacted in July 5, 1965; and Tyrol State Law number 54, enacted in November 21, 1988.
} 
abstainers must be sent a message from the government informing them about the importance of voting under a democratic state. ${ }^{56}$

Sanctions for abstention in presidential elections were initially capped at 1,000 schillings ${ }^{57}$ ( 506 USD). In 2004, the last presidential election in which any state had CV, this sanction could amount to 72 euros ( 97 USD in December 2015). ${ }^{58}$ The maximum fine for non-voting in parliamentary elections was also initially set at 1,000 schillings, but unlike presidential elections, the national law regulating parliamentary elections also established that failure to settle this fine was punishable by up to four weeks in jail. ${ }^{59}$ In 1971, maximum sanctions for abstention in parliamentary elections were increased to 3,000 schillings (992 USD), but maximum imprisonment for not paying the fines was lowered to two weeks. ${ }^{60}$

\section{Appendix C Additional Discussion and Results}

\section{Effect of the 1992 Elimination of CV on Turnout, Invalid Votes, and Spending.}

Table A.8 show the results of our difference-in-difference regression limiting our sample to the parliamentary elections in the electoral periods between 1986 and 2011, in which the only change in CV laws was federally enacted in 1992. This law forced Vorarlberg, Styria, Tyrol and Carinthia to eliminate $\mathrm{CV}$ in parliamentary elections. ${ }^{61}$ The magnitude and statistical significance of the results is remarkably similar to those shown in Tables 3 and 4 . The repeal of CV in 1992 causes a decrease in turnout in parliamentary elections of 9.8 percentage points, and an increase in invalid ballots of 1.3 percentage points. Likewise, in neither of our specifications do we find that CV affects fiscal policy. Due to the short time period covered in these regressions, we don't include state specific trends. Controlling for state-specific time trends, the repeal of CV in 1992 causes a decrease in turnout of 3.75 percentage points (significant at the $10 \%$ level), and an increase in the proportion of invalid ballots by 0.20 percentage points, although the latter is statistically insignificant. Furthermore, the results for our spending regressions are quantitatively similar when we control for state trends. These results suggest

\footnotetext{
${ }^{56}$ Carinthia state law issued in April 7, 1986, Article 3(3).

${ }^{57} 1957$ Federal Presidential Election Law, Article 25.

${ }^{58} 2002$ Federal Presidential Election Law, Article 23(3).

${ }^{59}$ Federal Parliament Election Law, Article 105 (3).

${ }^{60}$ Article 109 (3) of the 1971 Federal Parliament Election Law.

${ }^{61}$ The estimation equation is given by: $y_{s t}=\alpha_{0}+\alpha_{1} C V_{s} * \operatorname{Pre}_{t}+X_{s t} \beta+\delta_{s}+\nu_{t}+\epsilon_{s t}$. As in our previous specifications, $y_{s t}$ is an election outcome variable or expenditures in state $s$ and year $t ; C V_{s}$ is a dummy variable indicating whether voting was compulsory in state $s$ before the 1992 constitutional amendment, $\mathrm{Pre}_{t}$ is a dummy for the elections before 1992, $X_{s t}$ is a vector of state-year covariates (population and the unemployment rate), $\delta_{s}$ and $\nu_{t}$ are state and year fixed effects and $\epsilon_{s t}$ is the error term. Our interest lies in the coefficient that measures the difference-in-difference between states with and without CV, before and after the reform, $\alpha_{1}$. For comparison with previous tables, we introduce the "Pre" instead of "Post" dummy because after 1992, CV was repealed, rather than introduced.
} 
that any other changes in CV (besides the 1992 one) are unlikely to be correlated with trends in the main dependent variables.

Political Competition. For our analysis of political competition, we do not perform analyses for presidential elections because parties do not run as separate entities in those races. Instead, they form coalitions that cross party lines and change over time, making it impossible to identify the proportion of votes for right and left wing parties. In 1974, for e.g., the candidate nominated by the socialist SPÖ won the presidential election. This candidate was reelected in the 1980 elections, where he received support from the SPÖ but also from the right-wing ÖVP party. With respect to our state and parliamentary election regressions, although we only report the results considering vote shares for left (SPÖ + KPÖ) and right wing (ÖVP + FPÖ) parties, we also run regressions using the individual vote shares of these parties and find no effect. We also checked whether there was any impact on voter polarization, and find that there is no effect of $\mathrm{CV}$ on the sum of vote shares for the two main parties (SPÖ and ÖVP).

CV Effects by Heterogeneity in Turnout. An additional test of our hypothesis is to explore the heterogeneity of the effect between low vs. high turnout states. If it is indeed the case that voters who turn out to vote only because of the introduction of CV do not have different preferences than those who vote despite the absence of $\mathrm{CV}$, this effect should not depend on the baseline level of turnout, or even on the size of the "first stage" (i.e., the effect of $\mathrm{CV}$ on turnout). The results (available upon request) show that the effect of $\mathrm{CV}$ is larger in low turnout states, though the effect is not always statistically significant. This result is consistent with Funk (2007), who documents that the effect of the abolition of CV (a law with low or no sanctions) in Swiss cantons is larger in places with lower baseline turnout. She argues that low baseline turnout is related to a social norm, thus in places in which the social norm was stronger, the effects of an expressive law were undermined. However, despite the heterogeneity that shows up in the first stage, the effect of $\mathrm{CV}$ on the composition and level of spending at the state level remains very close to zero and statistically insignificant in most cases.

Further Details on Elections. In Austria, elections occur for five bodies/offices: (1) The National Council (henceforth "parliamentary elections"), (2) State parliaments ("state elections"), (3) Federal President ("presidential elections"), (4) Municipal council, and (5) The European Parliament. Throughout the paper, we focus exclusively on the first three.

CV and Transmission of Political Information. One way that CV could affect turnout and other outcomes is by affecting political information. When voting is compulsory, this 
may change the incentive of voters to acquire political information and/or may also affect the incentive of parties to transmit information in political campaigns. To examine whether CV affects voters' acquisition of information, we repeated the first regression in Table 6, but using newspaper reading as the outcome instead of turnout. We found no significant relation between $\mathrm{CV}$ and newspaper reading, though we recognize this is only a coarse measure of information acquisition. We do not have data on the campaign activities of political parties, so we cannot examine whether parties change their behavior. Overall, transmission of political information could be an important mechanism for our results, but it is difficult for us to examine this empirically. 